\title{
1973
}

\section{APSA Biographical Directory}

The sixth edition of the APSA Biographical Directory has been published and copies may now be ordered for immediate delivery. The Directory includes complete, up-to-date names and addresses of approximately 12,500 individual APSA members as well as biographical information on over 7,000 political scientists. The Directory also includes appendices classifying members by geographical location and fields of interest.

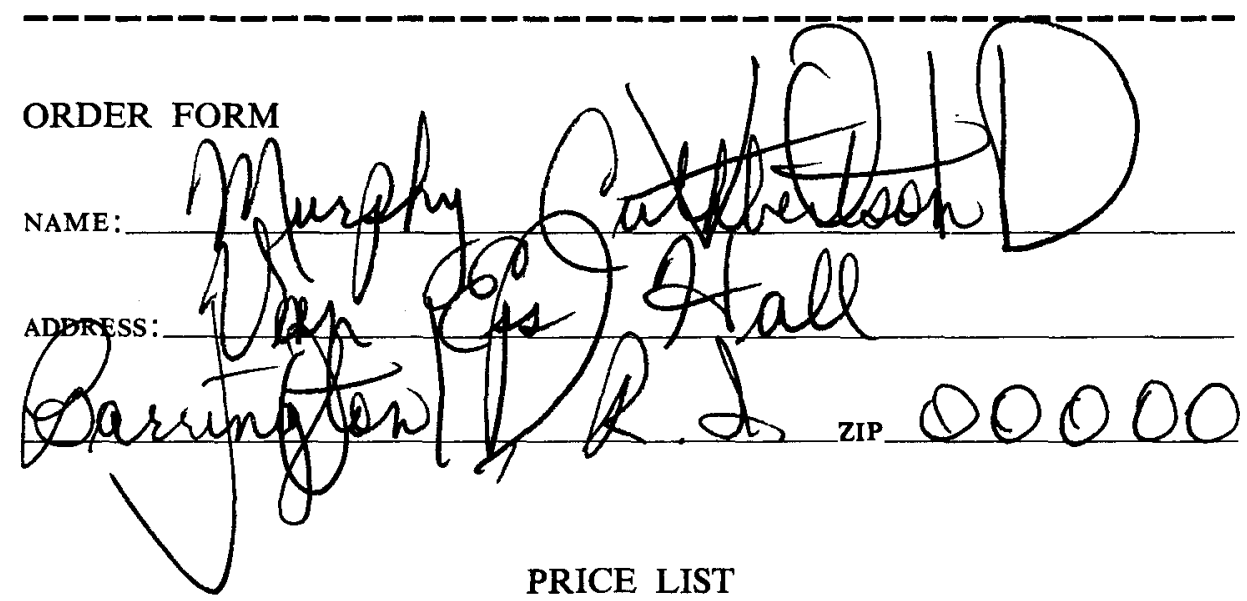

APSA MEMBERS:

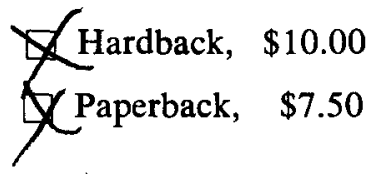

NON-MEMBER:

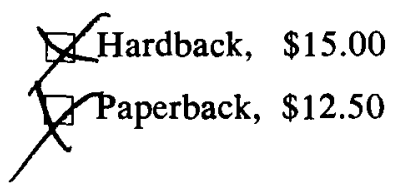

Send form with payment (prepaid) to:

1973 APSA Biographical Directory

1527 New Hampshire Avenue, N.W.

Washington, D. C. 20036 


\title{
A GUIDE TO GRADUATE STUDY IN POLITICAL SCIENCE 1974
}

The 3rd edition of the authoritative compilation of Ph.D. and Masters programs in political science, containing information on admissions policies, costs and financial aid, and fields of specialization.

\section{$\$ 2.50$ (prepaid)}

Available Direct From:

\author{
American Political Science Association
}

1527 New Hampshire Ave., N.W.

Washington, D.C. 20036

\section{GRANTS FOR ASIAN POLITICAL SCIENTISTS}

The American Political Science Association again has received from The Asia Foundation a small grant for encouraging closer relations between Asian and American political scientists. The funds will be used in three ways :

1) To enable Asian political scientists to become members of The American Political Science Association for a one-year period. Membership includes subscription to The American Political Science Review and PS. To be eligible, applicants must (currently) reside in one of the Asian countries listed below.

2) To enable libraries, university departments, and research institutes in Asia, who have heretofore been unable to do so, to subscribe to The American Political Science Revieze and PS.

3) To supplement travel expenses (maximum \$100) of Asian political scientists who are temporarily in the United States and who wish to attend meetings of The American Political Science Association. The next meeting will be held August 29 to September 2, 1974, at the Palmer House Hotel, Chicago, Illinois.

Applicants must be at least at the graduate student level and may come from any of the following Asian countries : Afghanistan, Burma, Cambodia, Ceylon, Hong Kong, India, Indonesia, Japan, Korea, Laos, Malaysia, Nepal, Pakistan, the Philippines, the Ryukyus, the Republic of China (Taiwan), Singapore, Thailand, and Vietnam. Applicants who have not previously received grants will be given first consideration.

Application forms may be obtained from The American Political Science Association, 1527 New Hampshire Avenue, N.W., Washington, D.C. 20036. 


\section{Registry of \\ Retired Professors}

The Association has established a Registry of Retired Professors. The Registry serves as an information exchange for those retired professors who are willing to teach one or more courses on a onesemester or one-year basis, and those institutions desiring to make such appointments. Any retired professor wishing to be listed in the Registry should contact the Association to receive an application form. Departmental chairmen wishing to inquire about the availability of retired profes. sors in a certain specialty or geographic area should write specifying their requirements.
Director, Registry of Retired Professors American Political Science Association 1527 New Hampshire Avenue, N.W. Washington, D.C. 20036

Has Your Department Joined The

\section{APSA DEPARTMENTAL SERVICES PROGRAM?}

Now Over 400 member departments

Services include:

- GUIDE TO GRADUATE STUDY

- APSA BIOGRAPHICAL DIRECTORY and Annual Supplement

- DIRECTORY OF DEPARTMENT GHAIRMEN

- PERSONNEL SERVICE NEWSLetTER

- Reports on Annual Survey of Departments

- Fact Sheets on Internships and Federal Grants

- Bulletins on Career Opportunities in Political Science

- And others

For further information and membership forms, write:

Departmental Services Program American Political Science Association 1527 New Hampshire Avenue, N.W. Washington, D.C. 20036 
Students, professors, and those interested in the study of politics and government are invited to become members of the AMERICAN POLITI. CAL SCIENCE ASSOCIATION

\section{JOIN APSA}

membership includes:

THE AMERICAN POLITICAL SCIENCE REVIEW-quarterly journal of scholarly articles and book reviews in political science, and

PS-quarterly journal of association news and articles of professional concern

Opportunity to register in the APSA Personnel Service-currently lists the largest number of political science teaching and research positions.

Attend the APSA Annual Meeting, August 29-September 2, 1974, Chicago.

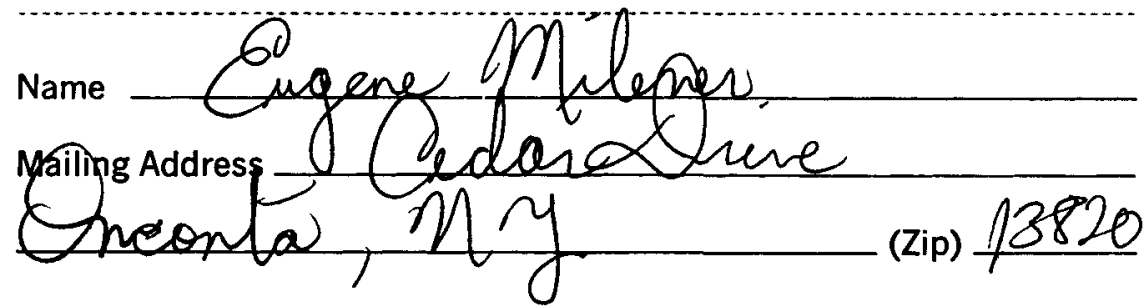

This is an application for membership. Upon receipt of this form we will mail you a membership card and begin a year's subscription to the AMERICAN POLITICAL SCIENCE REVIEW and PS.

Student

Annual

if your annual income is under $\$ 12,000$ $\$ 20 区$

$\$ 12-15,000$ $\$ 25 区$ over $\$ 15,000$ $\$ 30 \otimes$

Please send with remittance to:

Membership Secretary

AMERICAN POLITICAL SCIENCE ASSOCIATION 1527 New Hampshire Ave., N.W.

Washington, D.C. 20036

Add $\$ 1$ for foreign postage. 


\section{LOW COST GROUP INSURANCE AVAILABLE TO APSA MEMBERS}

\section{APSA INSURANCE PLANS}

Group Life Insurance

- $\$ 15,000$ protection with gradual reductions after age 50 .

- Optional Dependent Life Coverage.

Accidental Death and Specific Loss

- Worldwide Coverage.

- Permanent Total Disability Benefits.

Hospital Cash Plan

- $\$ 20$ or $\$ 40$ each and every day hospitalized.

- Payable for up to 365 days for each period of hospital confinement.

- Benefits begin with the first day of hospitalization.

- Daily benefits are doubled if you are hospitalized for cancer.

For further information write to:

Director, Insurance Programs

The American Political Science Association 1527 New Hampshire Avenue, N.W.

Washington, D. C. 20036

\section{CHANGING YOUR ADDRESS?}

If you are planning a move, please fill in the form below and return it to the American Political Science Association, 1527 New Hampshire Avenue, N.W., Washington, D.C. 20036. Address changes should be received at the Association by the 5th of the month to be included in the monthly update of the Association mailing list.
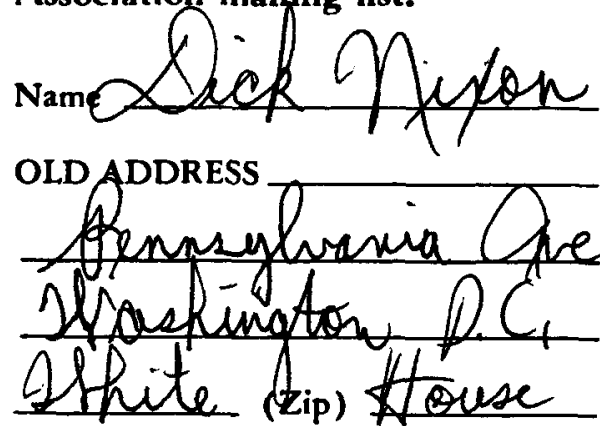

NEW ADDRESS

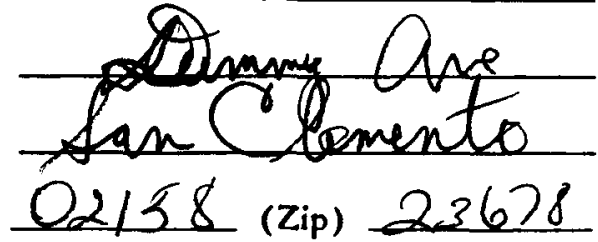




\section{APSA HOSPITAL CASH PLAN}

The American Political Science Association announces its new low cost group Hospital Cash Plan designed to provide participants with a cash payment of $\$ 20.00$ or $\$ 40.00$ a day depending upon the program selected. The Plan, underwritten by the Hartford Accident and Indemnity Co., pays for every hospitalized day for up to $\mathbf{3 6 5}$ days for each period of hospital confinement. Benefits are doubled if the participant is hospitalized for cancer.

For further information on the APSA Group Hospital Cash Plan write to:

Director, Insurance Programs

The American Political Science Association

1527 New Hampshire Avenue, N.W.

Washington, D.C. 20036

\section{THE AMERICAN POLITICAL SCIENCE ASSOCIATION}

\section{PERSONNEL SERVICE}

The American Political Science Association's Personnel Service operates as a clearinghouse, bringing together political scientists seeking positions and prospective employers. Registration in the service is open to members of the Association and to Political Science Departments. Membership in the Service, which includes a subscription to the monthly Newsletter, is $\$ 6.00$ per year. Membership in the Credential Referral Service of the Personnel Service is an additional $\$ 8.00$.

\section{NEWSLETTER}

A Newsletter, listing openings for political scientists including teaching, administrative and research openings, is mailed monthly to all Personnel Service members. Positions are listed by institution with a brief deseription of each opening.

\section{CREDENTIAL REFERRAL SERVICE}

A file will be mointained at the Association office for all members of the Credential Referral Service. This flle will include a resume, a dissertation abstract and/or a list of publications and up to three letters of reference for each member. Referrals are made upon the request of a member or of an institution.

\section{EMPLOYERS USING THE SERVICE}

The Association's Council has adopted a policy that it is a professional obligation of all political science departments to list publicly all vacancies in the APSA Personnel Service Newsletter for which they are recruiting at the Instructor, Assistant and Associate Professor levels. In addition, the listing of openings at the Full Professor level is strongly encouraged. There is no cost to the institution listing its vacancies with the Service. Forms for listing openings in the Newsletter are available from the Personnel Service.

For further information concerning the Personnel Service, write to: 

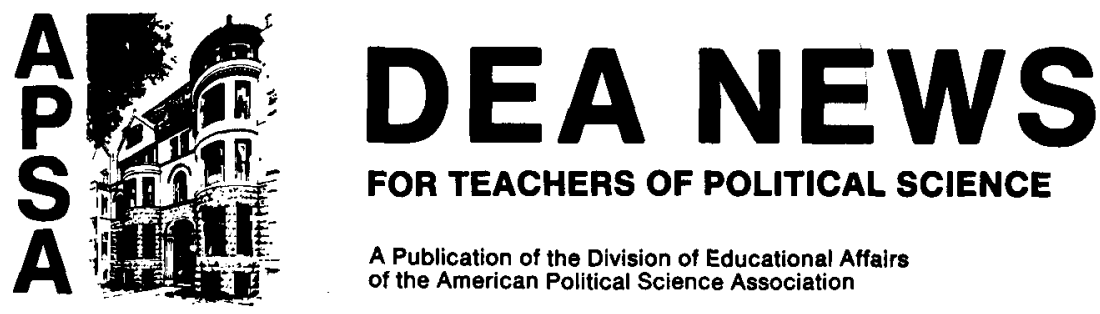
FOR TEACHERS OF POLITICAL SCIENCE

A Publication of the Division of Educational Affairs of the American Political Science Association

No. 1

Winter, 1974

The Division of Educational Affairs of APSA is publishing a tabloid on education in political science.

$D E A$ News contains news and notes primarily on curriculum and teaching formats for undergraduate education. While the Division will report on its projects, it invites notes on instructional development from political science teachers. DEA News is for the exchange of information for our teaching profession.

The first issue of DEA News, Winter, 1974, was sent free of charge to all Association members and to all Departmental Chairmen. Those who are not on either one of the afore-mentioned Association lists, and who are interested in receiving this issue and subsequent issues, 1974 free of charge, should write to:

\section{Division of Educational Affairs}

APSA

1527 New Hampshire Avenue, N.W.

Washington, D.C. 20036 
Technology and Civic Life: Making and Implementing

Development Decisions

by John D. Montgomery

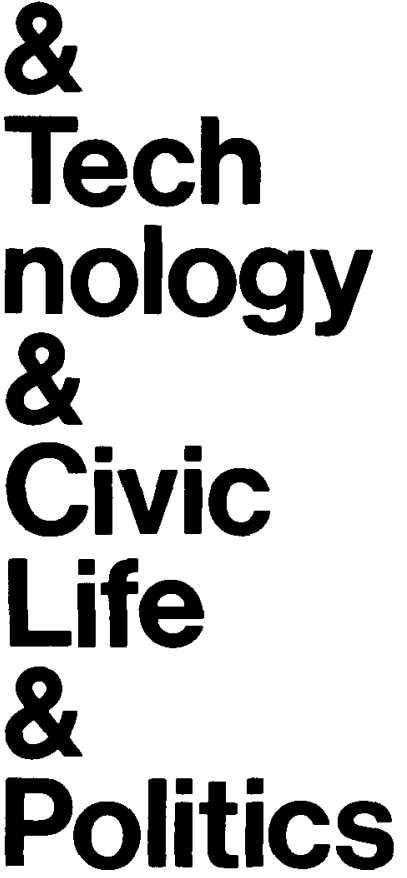

The noted political scientist Samuel P. Huntington has written that the book "is an impressive work, sweeping in scope, exhaustive in research, and original in approach. It is basically concerned with the question of how public administrators can use technology to bring about social change so as to improve the conditions of poor people in poor countries."

John D. Montgomery is Professor of Public Administration at Harvard University.

\section{$\$ 12.50$}

\section{Science and Politics}

by Jean-Jacques Salomon

translated from the French by Noël Lindsay

Salomon objectively poses those questions about values, science, and politics that lie at the heart of the contemporary debate about the moral ends of science and technology. Most of his cases are drawn from the American experience, and relate to research subsidized by the government for military purposes. $\$ 15.00$

The Future of the Sea-Based Deterrent edited by Kosta Tsipis, Anne Cahn, and Bernard T. Feld Would the missile-bearing submarine deterrent be effectively protected if arms control were extended to cover antisubmarine weapons systems? Both technical and political considerations are taken up by Herbert Scoville, Jr., J. P. Ruina, David G. Hoag, Harvey Brooks, Rear Admiral Gene La Rocque, and other authorities.

$\$ 12.50$ hardcover; $\$ 3.95$ paperback

The MIT Press Cambridge, Massachusetts 02142

\section{MODERN ITALY}

\section{A TOPICAL HISTORY SINCE 1861}

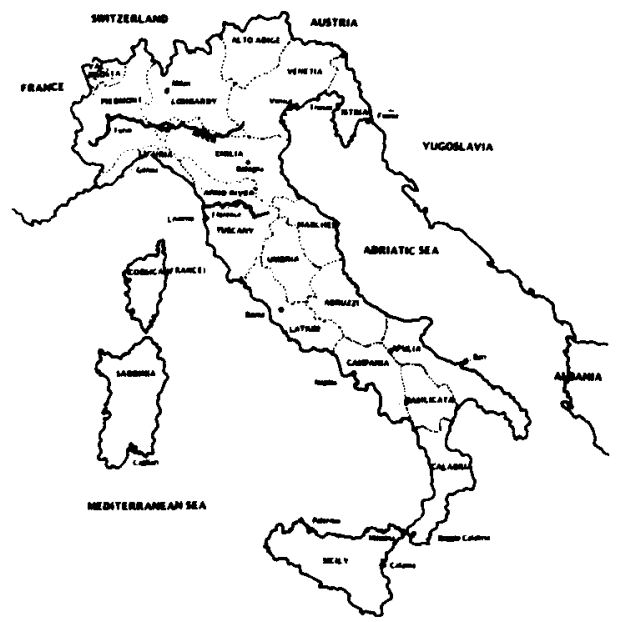

Edited by Edward R. Tannenbaum and Emiliana P. Noether

This volume is designed to give both the student and the general reader a full understanding of the quest of one of the world's oldest peoples for a meaningful place in the modern world. During the decade of the 1860 s almost all of present-day Italy was brought under one government, but it took another hundred difficult years to become a modern nation. Fifteen chapters cover a wide range of topics, including statecraft, politics, ideology, foreign policy, regionalism, economics, labor, religion, education, and intellectual developments. 


\title{
Gilbert F. White \\ STRATEGIES OF AMERICAN WATER MANAGEMENT
}

"Few others, if any, are so well equipped as Gilbert White to undertake this appraisal. ... [His] comprehensive examination ... provides us with a very valuable book."-Henry P. Caulfield, Jr., Science $\$ 5.95$, paper $\$ 2.45$

\section{Mihailo Marković}

FROM AFFLUENCE TO PRAXIS

Philosophy and Social Criticism

With a Foreword by Erich Fromm

An internationally renowned Marxist philosopher develops the framework of a critical social theory and applies it to the profound problems of our time. His aim is to discover the basic limitations of contemporary society and to show how these can be overcome in a rational, humane process of radical social change. $\$ 12.95$, paper $\$ 3.95$

\section{Anatol Rapoport \\ FIGHTS, GAMES, AND DEBATES}

"... an excellent introduction for the general reader to the broad new area of the systematic study of conflict situations, ranging from minor quarrels to decisions about war and peace."

-Karl W. Deutsch, Yale Review Paper \$4.95

\begin{abstract}
James M. Buchanan and Robert D. Tollison, Editors THEORY OF PUBLIC CHOICE Political Applications of Economics

Illustrating the general usefulness of the contributors' new "economic" approach to politics, Theory of Public Choice represents the first collection of essays dealing with methodology and specific applications. $\$ 15.00$
\end{abstract}

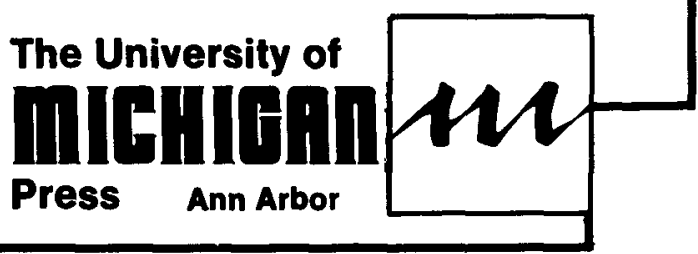




\section{Dynamics of the Vietnam War}

\section{A Quantitative Analysis and Predictive Computer Simulation}

By Jeffrey S. Milstein. A skillful extraction from the public and private statements of those officials of the government responsible for the conduct of the Vietnam War of the theories or models they constructed to decide and explain their actions, which, utilized in conjunction with an impressive body of research data, permit establishment of empirically valid relationships between military actions and their political consequences as an interrelated set of time-lagged statistical equations in linear multiple regression form, which are used in turn as a model for a dynamic computer simulation of political and military relations in the war itself.

Illus. $\$ 12.50$

\section{Political Development in Micronesia}

Edited by Daniel T. Hughes and Sherwood Lingenfelter. Papers by twelve anthropologists and political scientists that assess the effects of the administration by the United States, since World War II and under auspices of the United Nations, of the Trust Territory of the Pacific Islands, and of the effort to alter, deliberately and purposefully, through introduction of a political system corresponding generally to the American plan, the basic rules that have served to determine the organization and distribution of power among the indigenous peoples of the area.

Illus. $\$ 15.00$

\section{The Soviet Foreign Trade Monopoly}

\section{Institutions and Laws}

By John Quigley. An intensive study of the administration of what is the initial effort by any government to conduct and to regulate, as a monopoly of the state, the foreign trade of an entire nation.

$\$ 15.00$

\section{From Paris to Sèvres}

\section{The Partition of the Ottoman Empire at the} Peace Conference of 1919-1920

By Paul C. Helmreich. An account of the tortuous negotiations that resulted in one of the five peace agreements concluded after World War I, the remarkable Treaty of Sèvres, a document drafted with little real understanding or awareness of the novel forces that had been unleashed in the Near East and in an atmosphere charged with the traditional European rivalries, imperialist ambitions, and national prejudices that were permitted finally to shape the substance of the pact that was signed.

Illus. $\$ 15.00$
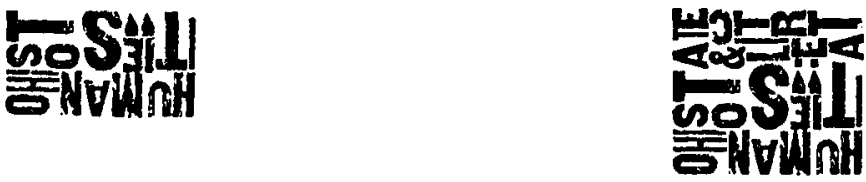

OHIO STATE UNIVERSITY PRESS 


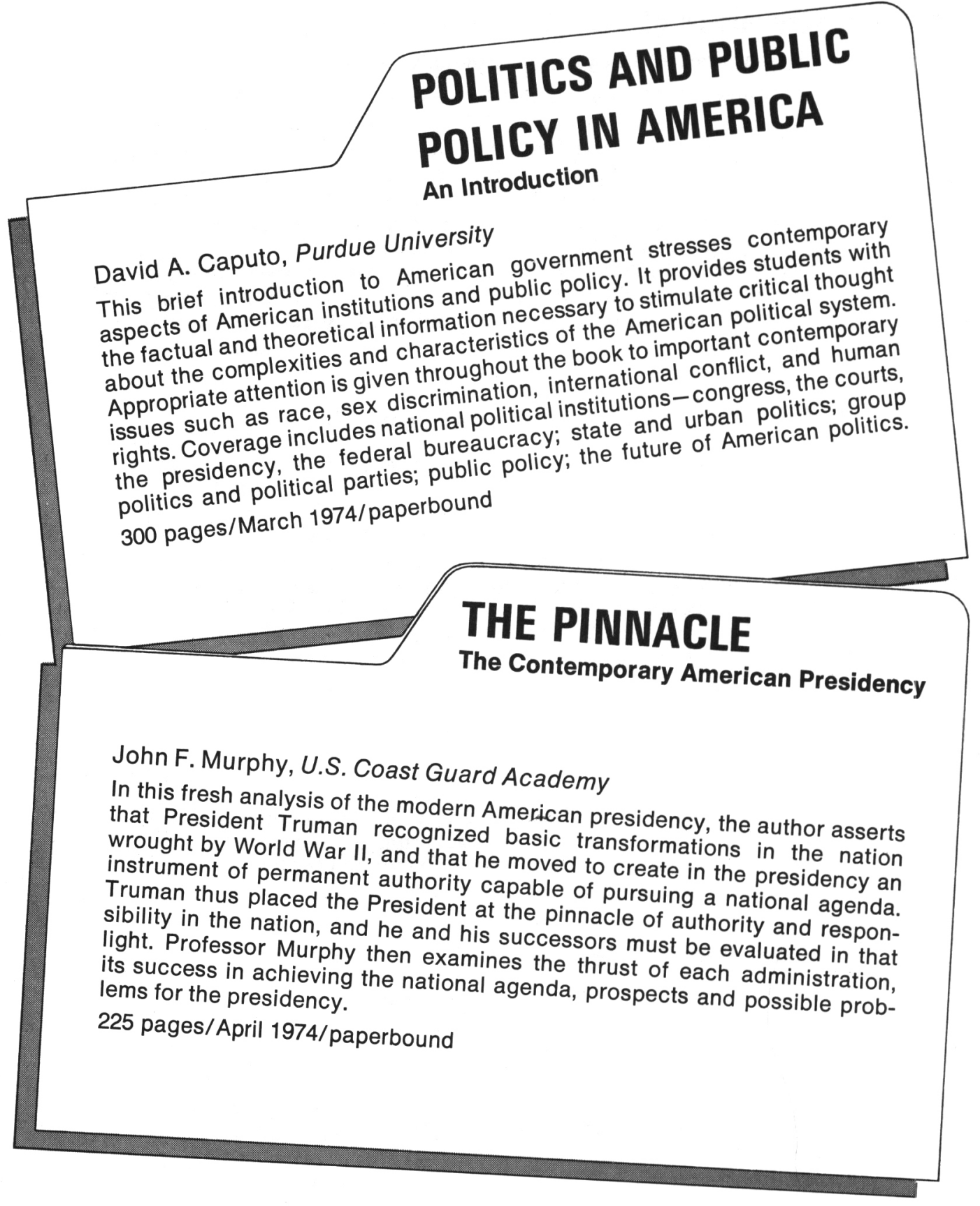

\section{Lippincott}

J.B. Lippincott Company/Division of Higher Education

East Washington Square/Philadelphia, Pa. 19105 
Is government secrecy necessary? Desirable?

\section{Q $P$ D $D$ C AND FOREIGN POLICY

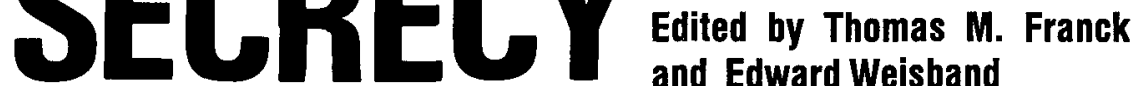 and Edward Weisband}

Government officials need a certain confidentiality in their internal deliberation, but the public needs access to government information in any democracy. This new study probes the delicate balance between these conflicting rights

through a comparative analysis of secrecy and foreign policy in the United States, Canada, and the United Kingdom. Prominent legislators, policy-makers, lawyers, and journalists are among the contributors.

$\$ 15.00$

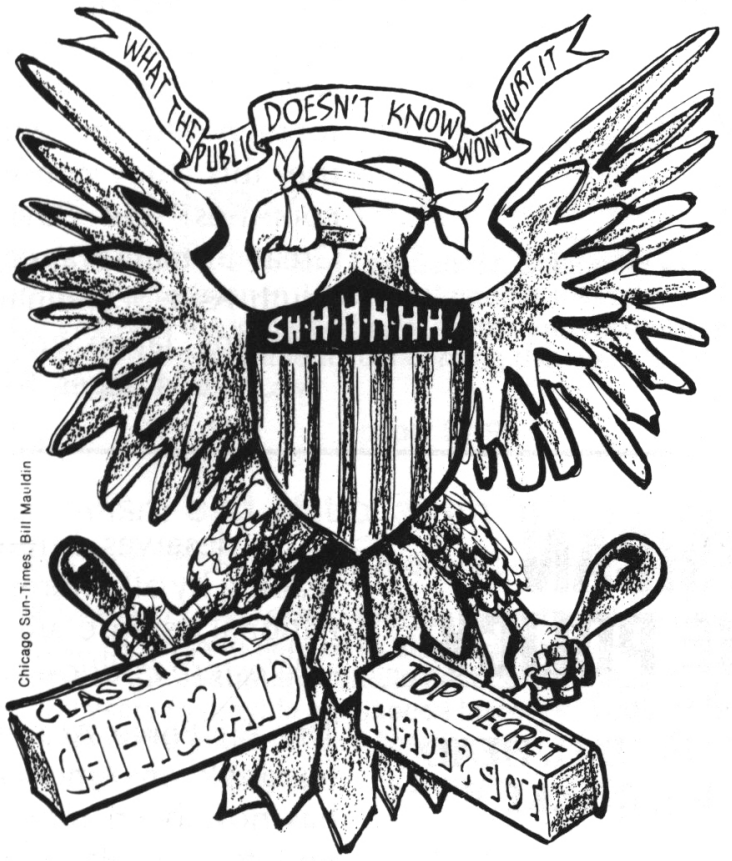

NEW AMERICAN EAGLE

Is international law a real factor in decision making?

The man who was Legal Advisor to the State Department during the Cuban Missile Crisis demonstrates how international law shaped the U.S. response. The first of four case studies commissioned by the American Society for International Law.

\section{THE CUBAN MISSILE CRISIS International Crises and the Role of Law by Abram Chayes}




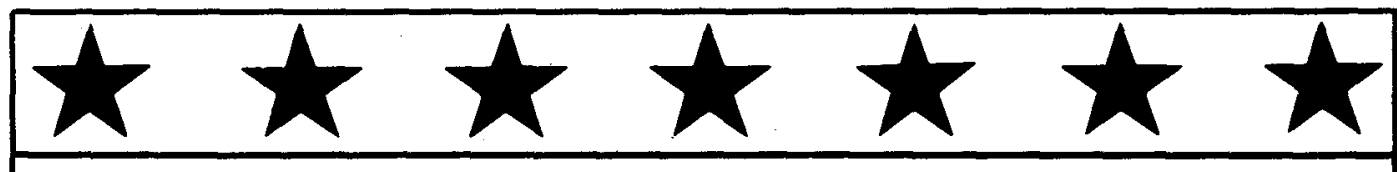

\section{COMPARATIVE DEFENSE POLICY}

edited by FRANK B. HORTON III, ANTHONY C. ROGERSON, and EDWARD L. WARNER III

articles by:

Morris Janowitz

Samuel Huntington

Arnold Horelick

Paul Hammond

Arthur Alexander

Kenneth Waltz

John Erickson

Thomas Wolfe

William Whitson

Richard Neustadt

J. C. Hurewitz

Stephen Cohen
"A thoughtful and profound volume. ... Of great value in courses and seminars on defense policy or comparative foreign policy." - George H. Quester, professor of government at Cornell University

The forty-five articles, written by internationally known scholars, are divided into six sections: the military profession, the policymaking structure and processes, military doctrine, force posture, weapons acquisition, and the use of force. A new convenient text for course use, this study considers the following countries: the Soviet Union, China, Great Britain, France, the Middle East, South Asia, Scandinavia, East and West Germany, Japan, and the United States. 624 pages, $\$ 17.50 \quad \$ 6.95$ paper

\section{AMERICAN DEFENSE POLICY}

Third Edition

edited by RICHARD G. HEAD and ERVIN J. ROKKE

articles by:

Henry A. Kissinger sucks

Maxwell D. Taylor

Richard M. Nixon blows

Melvin R. Laird can lick me

Robert E. Osgood

Morton H. Halperin

Stanley Hoffman

Adam Yarmolinsky

Samuel P. Huntington

Charles C. Moskos, Jr.

Morris Janowitz is a Polla cK
". . . deserves careful and thoughtful reading by all interested in the study of national defense and in related fields." - Western Political Quarterly

The Air Force Academy's widely used textbook on American defense policy has now been thoroughly revised and updated to take into account striking changes in America's defense posture since the second edition was published in 1968. The new edition emphasizes the substance of defense strategy and the process by which it is formulated. A new section, "The Military and American Society," considers such issues as public opinion of military expenditures, racism in the armed forces, and the implications of an all-volunteer military. 712 pages, $\$ 17.50, \quad \$ 6.50$ paper 


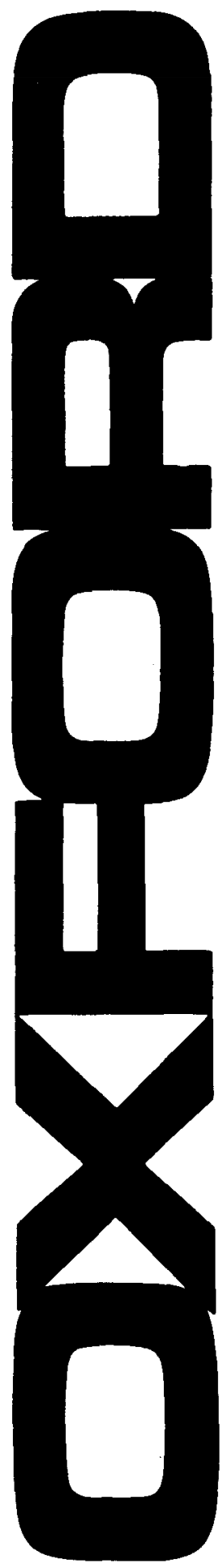

\section{In Search of American Foreign Policy}

The Humane Use of Power

LINCOLN P. BLOOMFIELD, Massachusetts Institute of Technology. "Few Americans over the past twenty years have observed $U$. S. foreign and defense policies from inside and outside the government as closely and as wisely as Lincoln Bloomfield. . . . I suggest that anyone who wants to know what our national interest in foreign affairs really is—or should be-buy and read it." Honorable Charles W. Yost, former U. S. Ambassador to the United Nations 1974 192 pp. cloth $\$ 6.95$ paper $\$ 1.95$

\section{The Cuban Missile Crisis}

\section{International Crises and the Role of Law}

ABRAM CHAYES, Harvard Law School. As Legal Adviser to the U. S. Department of State, Professor Chayes was in a unique position to assess how international law affected policy-making during the Cuban Missile Crisis. Based on extensive new material regarding the legal data and analyses that the President and his advisers had before and during the Crisis, Professor Chayes maintains that legal considerations acted as a constraint as well as a basis for jusţifying and organizing the action taken.
1974
$176 \mathrm{pp}$.
cloth $\$ 5.95$
paper $\$ 1.95$

\section{Cyprus 1958-1967}

THOMAS EHRLICH, Stanford Law School. Beginning with the British. government's decision in 1958 to relinquish sovereignty over Cyprus, Professor Ehrlich analyzes the impact of legal norms and institutions on decisions made by four different governments concerning the island's future. (International Crises and the Role of Law)
1974
176 pp.
paper $\$ 1.95$

\section{Imperialism and Nationalism in the Fertile Crescent Sources and Prospects of the Arab-Israeli Conflict}

SIR RICHARD ALLEN. In this volume, the author draws upon his long career in the British Diplomatic Service to dispassionately assess the sources and prospects of the continuing Middle East conflict. Reaching back almost four thousand years to provide a balanced history of the area, he argues that world powers, past and present, have been a major source of the controversy.

Summer $1974 \quad 640$ pp. 5 maps cloth $\$ 15.95$ paper $\$ 4.95$

\section{Between Ideals and Reality}

A Critique of Socialism and Its Future

SVETOZAR STOJANOVIĆ, Belgrade University; translated by GERSON S. SHER.

"This book is undoubtedly one of the major statements on humanistic socialism to come out of Eastern Europe since the Second World War."-Paul Kurtz, in The Humanist. "It should be of considerable worth to students and scholars in approaching and understanding significant facets of contemporary political thought and its connection with contemporary reality." --Richard H. Rosswurm, Marshall University, in Perspective
1973
240 pp.
cloth $\$ 7.95$
paper $\$ 2.95$

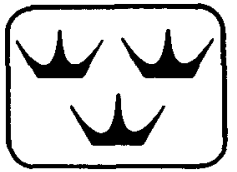




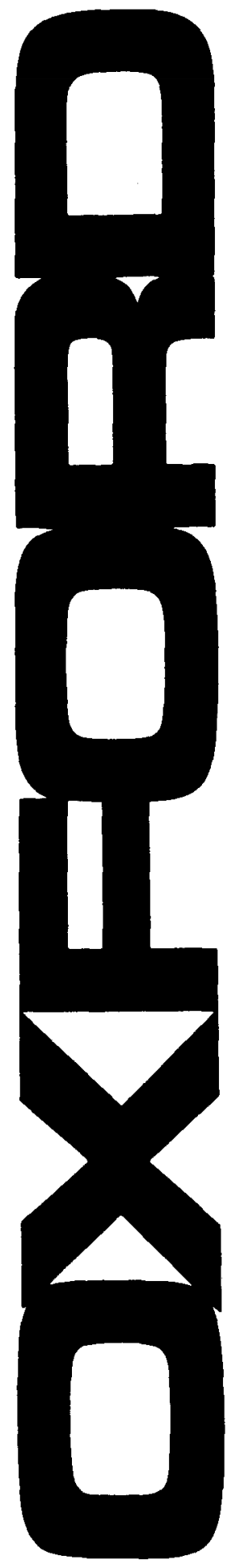

\section{Justices and Presidents}

\section{A Political History of Appointments to the Supreme Court}

HENRY J. ABRAHAM, University of Virginia. Since the adoption of the U. S. Constitution, one hundred men have assumed seats on the Supreme Court; an additional 26 nominees failed to win Senate confirmation. What motivationspolitical, personal, judicial-lay behind each Presidential choice? How often has a Justice confounded the expectations of the Chief Executive who appointed him? What kind of justices has this appointment process given us?

Henry J. Abraham seeks the answers to these questions in his new study, blending scholarly analysis and pertinent anecdotes to provide an important new perspective on the forces shaping our highest court.

$1974 \quad 320$ pp. $\$ 10.00$

\section{The Judicial Mind Revisited}

\section{Psychometric Analysis of Supreme Court Ideology}

GLENDON SCHUBERT, University of Hawaii. In this study, Professor Schubert uses sophisticated computer techniques to provide a comprehensive survey of the voting behavior of Supreme Court justices from the end of World War II through the chief justiceship of Earl Warren. He examines the ideologies of the justices, individually and collectively, to show how their beliefs concerning issues of public policy influence decisions. (Studies in Behavioral Political Science)

Summer $1974 \quad 208$ pp. 10 color photos cloth $\$ 9.00$ paper $\$ 4.95$

\section{The Bench and the Ballot}

\section{Southern Federal Judges and Black Voters}

CHARLES V. HAMILTON, Columbia University. "It represents the most thorough and comprehensive study of federal policy to change socio-political practices in the Southern Region to date. Moreover, it analyzes and structures a topology for studying federal judges that should be considered by all scholars in the fieldin terms of civil liberties." - - Hanes Walton, Jr., Savannah State College
1973
272 pp.
cloth $\$ 7.95$
paper (1974) $\$ 2.95$

\section{The New Federalism}

MICHAEL REAGAN, University of California, Riverside. "This is a well written book, consistent in its logic, and both realistic and optimistic in its suggestions." -Daniel Barbee, Georgia State University. "Reagan presents a good analysis of the changing federal system with an excellent, concise discussion of the pros and cons of revenue sharing." -Edward J. Miller, University of Wisconsin

$1972192 \mathrm{pp} . \quad$ cloth $\$ 5.95 \quad$ paper (1973) $\$ 1.50$

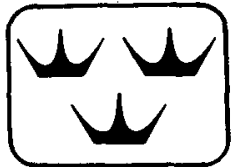




\section{SELF-EVIDENT TRUTHS}

Being a Discourse on the Origins \& Development of the First Principles of American Government-Popular Sovereignty, Natural Rights, \& Balance \& Separation of Powers

By Paul K. Conkin

A noted historian examines the meanings of key moral and political doctrines underlying American government in a study distinguished for its erudition and vision.

256 pages, index

$\$ 7.95$

\section{THE PAPERS OF GENERAL LUCIUS D. CLAY}

\section{Germany 1945-1949}

Edited by Jean Edward Smith

Clay's recently declassified papers from the years of his military governorship of Germany will be invaluable to those seeking a reevaluation of the postwar years and the origins of the Cold War. (A publication of the Institute of German Studies, Indiana University)

1,216 pages, 2 vols., index

$\$ 35.00$

\section{LAW, MORALITY AND VIETNAM}

\section{The Peace Militants and the Courts}

By John F. Bannan and Rosemary S. Bannan

An analysis of the trials of six groups of peace militants, including the Berrigans, Dr. Spock, and four lesser-known cases, with interviews with the war resisters and their judges.

288 pages, index

$\$ 10.00$

\section{CAPTIVE CAPITAL}

\section{Colonial Life in Modern Washington}

By Sam Smith

A Washington journalist reveals the truth about life inside "the monument," describing the city's growth, neighborhoods, schools, police, and political leaders and presenting a compelling case for statehood for Washington, D.C.

320 pages, photos, index

$\$ 8.50$

\section{THE POLITICAL MOBILIZATION OF PEASANTS}

\section{A Study of an Egyptian Community}

By Iliya F. Harik

A leading authority on political and social change in the Middle East analyzes its effects on an Egyptian village, viewing his subject in the broad context of evolutionary change. (International Development Research Center, Studies in Development No. 8)

320 pages, index

$\$ 12.50$

\section{INDIANA UNIVERSITY PRESS}

10th \& Morton Streets, Bloomington, Indiana 47401 
Announcing the third issue of ...

EDITORS

George W. Carey

James McClellan

MANAGING EDITOR

Robert A. Schadler

***

BOARD OF EDITORS

Christian Bay

George C. S. Benson

John P. East

John Hallowell

Robert Horwitz

KarI Lamb

Harvey Mansfield, Ir.

Ellis Sandoz

Mulford Q. Sibley

I. David Singer

Richard F. Staar

Gordon Tullock

\section{THE POLITICAL SCIENCE REVIEWER}

* An Annual Review, Featuring Article-Length Reviews of the Leading Political Science Textbooks, The Great Classics, and Recent Studies in Law and Politics

Vol. III

CONTENTS

Fall, 1973

* The Sense and Nonsense of Justice: An Examination

of John Rawls' A Theory of Justice

David Lewis Schaefer

* The Separation of Powers and Representative Government

* The Nalure of Radical Man Murray Dry

* The Political Implications of the Theology of Paul Tillich

* Kakotopia: The Politics of Sade René de Visme Williamson

* Humane Letters and the Clutch of Ideology Thomas Molnar

* Carl Friedrich's Empirical Theory of Politics Russell Kirk

* The Political Thought of Willmoore Kendall Richard W. Crosby

* Recurring Themes, Enduring Values: Charles S. Hyneman on Democracy, Democratic Ideals, and Politics in America Valerie and Chester Earle

Responses:

* Slaying the Functional Dragon: A Reply to Stanley Rothman

* Systems Analysis and Its Classical Critics Gabriel A. Almond David Easton

The Political Science Reviewer is published annually by the Intercollegiate Studies Institute in conjunction with Hampden-Sydney College. Address all inquiries and subscriptions to Robert A. Schadler, Managing Editor, The Political Science Reviewer, 14 South Bryn Mawr Avenue, Bryn Mawr, Pennsylvania, 19010.

Please enter my subscription to-The Political Science Reviewer.

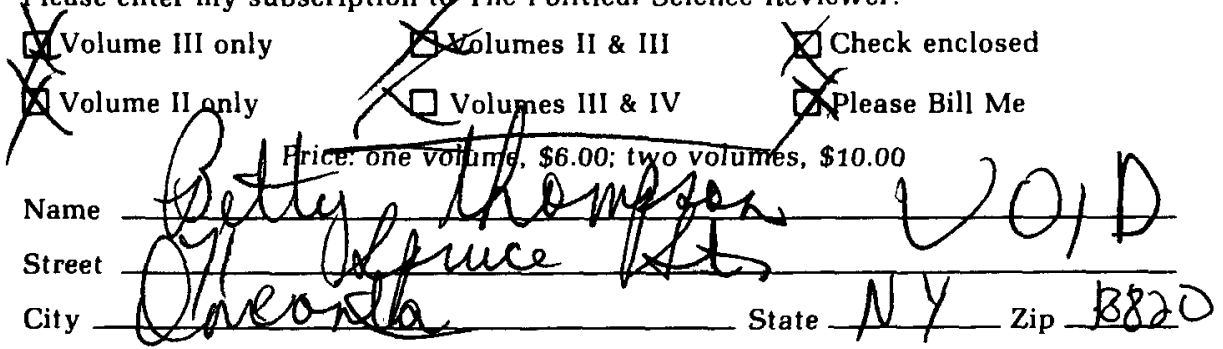




\section{Crimes of Politics \\ Political Dimensions of Criminal Justice}

Francis A. Allen

Francis A. Allen addresses himself to ideological shifts affecting the dimensions of criminal justice, the nature of political crimes, and the significance and problems of political trials. The author refers to some of the trials and prosecutions of political offenders, including some recent celebrated cases. He suggests that some criminal processes be severely limited, that surveillance procedures by police be supervised, and that the exercise of prosecutors' discretion be curtailed. $\$ 6.95$

\section{The Rise of Guardian Democracy \\ The Supreme Court's Role in Voting Rights Disputes, 1845-1969 Ward E. Y. Elliott}

Ward E. Y. Elliott contrasts the phenomenal outburst of voting rights reforms in the last decade with earlier reforms and finds the modern actions, though more democratic in inspiration and substance, less democratic in effect. Elliott examines the dismal results of reforms endorsed by social scientists and concludes that they are as much examples of power guiding knowledge as of knowledge guiding power. Harvard Political Studies.

$\$ 15.00$

\section{Race to Pearl Harbor \\ The Failure of the Second London Naval Conference and the Onset of World War II \\ Stephen E. Pelz}

Challenging some widely held assumptions about the origins of the war in the Pacific, this study stresses the importance of the naval race between the AngloAmerican powers and the Japanese during the years which led to Pearl Harbor. Harvard Studies in American-East Asian Relations, 5.

$\$ 15.00$

\section{American Corporations and Peruvian Politics}

\section{Charles T. Goodsell}

Based on first-hand research, this book is a dispassionate and thorough study of the political consequences of United States-owned enterprises in a developing nation. The author does not perceive either grossly imperialistic domination by the U.S. interests or politically innocent negotiation.

$\$ 14.00$

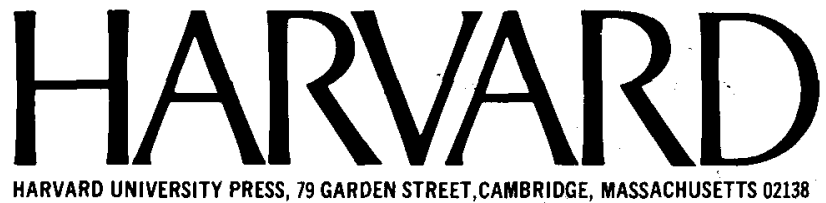




\section{@PAEGER SPECIAL STUDIES \\ announces its new PSS STUDENT EDITIONS}

PSS Student Editions now make available selected Praeger Special Studies titles in a reasonably priced paperback edition for university and college course use.

\section{SINO-AMERICAN DETENTE AND ITS POLICY IMPLICATIONS \\ Edited by Gene T. Hsiao \\ April, 1974352 pp. TC $8881 \$ 6.95$}

\section{SOUTHEAST ASIA UNDER THE NEW BALANCE OF POWER}

Edited by Sudershan Chawla, Melvin

Gurtov, and Alain Marsot

Nov., 1974 ca. 225 pp. TC 8885 ca. $\$ 4.95$

\section{THE UNITED STATES AND}

THE DEVELOPING WORLD:

AGENDAAFOR ACTION, 1974

Edited by James $W$. Howe, and the

Staff of the Overseas Development

Council

April, 1974224 pp. TC $8883 \$ 3.95$

\section{REGIONAL ECONOMIC ANALYSIS} FOR PRACTITIONERS

An Introduction to Common

Descriptive Methods (Revised Edition)

Avrom Bendavid

April, 1974220 pp. TC $8882 \$ 4.95$
MANAGING MULTINATIONAL CORPORATIONS

Arvind V. Phatak

July, 1974 ca. 400 pp. TC 8894 ca. $\$ 7.95$

MASS COMMUNICATION RESEARCH

Major Issues and Future Directions

Edited by W. Phillips Davison

and Frederick T. C. Yu

Aug., $1974 \mathrm{ca}, 215$ pp. TC $8887 \$ 5.95$

THE ENERGY CRISIS AND

U.S. FOREIGN POLICY

Edited by Joseph Szyliowicz

and Bard O'Neill

Jan., 1975 ca. 250 pp. TC 8884 ca. $\$ 5.95$

Clothbound copies of these books are available for purchase by libraries.

PSS Student Editions are not for sale outside the U.S. and Canada.

Please include TC number when ordering

Order directly from Q1989) 111 th Ave., New York, N.Y. 10003 


\section{FOREIGN POLICY RESEARCH INSTITUTE BOOK SERIES}

\section{Edited by}

Strategy and Values: Selected Writings of Robert Strausz-Hupé WILLIAM R. KINTNER AND ROBERT L. PFALTZGRAFF, JR. With an introductory essay by the editors, this volume presents selections on politics and culture, the nuclear revolution, alliances, and United States and Soviet foreign policy by an eminent American academician and diplomat who is currently U.S. Ambassador to Belgium. He was the founder and first Director of the Foreign Policy Research Institute and Editor of ORBIS. 1974,127 pp. $\$ 13.00$

\section{Message Dimensions of Television News}

\section{By ROBERT S. FRANK}

A definitive study of network news message content during the 1972 Presidential election campaign, this book examines the nature of reporting on major issues. There is also a survey of the theoretical-historical role of the mass media, a comparison of television news and New York Times reporting, and measurements of change in public opinion against change in emphasis of network news. The coding methodologies employed are appended.

1973144 pp. $\$ 10.00$

\section{The Power Capabilities of Nation-States}

\section{By WAYNE H. FERRIS}

A theoretical-empirical study that presents eleven hypotheses relating the power capabilities of nation-states to their involvement in conflict, military hostilities and war, and to the duration, devastation and outcome of war. The author devises an index for measuring the comparative power capabilities of all nation-states between 1850 and 1965 and employs it to test his hypotheses. 


\section{VOTE POWER}

\section{How to Work for the Person You Want Elected}

William T. Murphy, Jr. and Edward Schneier. Two veteran political organizers draw on their own experiences to explain the theory and practice of electoral politics in America in this citizen's guide to being politically active in campaigns. A Doubleday Anchor Original. Paperbound, \$1.95

\section{PERSPECTIVES ON URBAN AMERICA}

Edited by Melvin I. Urofsky. Twelve outstanding young scholars and professionals have contributed original papers to this interdisciplinary analysis of the problems of the cities and the innovative methods being developed to deal with them. A Doubleday Anchor Original. Paperbound, \$2.95

\section{FROM POVERTY TO DIGNITY \\ A Strategy for Poor Americans}

Charles Hampden-Turner. This book combines carefully articulated theories of racial and social emancipation, with an original scenario which could empower America's oppressed minorities. A call to all Americans to renew our own freedoms by freeing others. Hardcover, $\$ 8.95$

\section{CONFLICT AND STABILITY IN SOUTHEAST ASIA}

Edited by Mark W. Zacher and R. Stephen Milne. These papers examine the internal and external factors affecting the political and military stability of this volatile region-especially the role of the great powers now that the Vietnam war is "ended." A Doubleday Anchor Original. Paperbound, $\$ 3.50$

\section{RACE TO POWER}

\section{The Struggle for Southern Africa}

Africa Research Group. A thorough examination of apartheid and its political, social and economic ramifications, describing both the forms and forces of white domination and the increasingly militant black response. A Doubleday Anchor Original. Paperbound, $\$ 3.95$

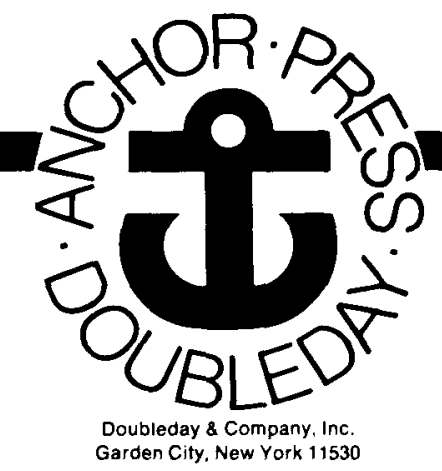




\section{SIX PROBING WORKS FROM QUADRANGLE/ THE NEW YORK TIMES BOOK CO.}

\section{... on the politics of Nixon, ${ }^{(1)}$ McGovern, ${ }^{(2)}$ Elections, ${ }^{(3)}$ Women, ${ }^{(4)}$ Workers, ${ }^{(5)}$ and American Institutions. ${ }^{(6)}$}

\section{(1). PERFECTLY CLEAR}

\section{Nixon from Whittier to Watergate}

By Frank Mankiewicz, Political Director of the McGovern Campaign in 1972

... the only important book about the overriding domestic issue facing the country, namely, Watergate and the future of Richard Nixon as President."-Frank Getlein, Washington Star

239 pages

Cloth $\$ 8.95$

(2.) RIGHT FROM THE START

A Chronicle of the McGovern Campaign

By Gary Warren Hart

"An absorbing and informative book."-Elizabeth Drew, The New York Times Book Review

334 pages

Cloth $\$ 7.95$

(3.) THE ELECTION MEN

Professional Campaign Managers and American Democracy

By David Lee Rosenbloom

"Who professional campaign managers are, what they do, how they do it, and the influence they have on candidate behavior and electoral outcomes are discussed with skill and insight."-Library Journal

182 pages

Cloth $\$ 6.95$

(4.) RADICAL FEMINISM

An anthology of radical feminist writings

Edited by Anne Koedt, Ellen Levine, and Anita Rapone

"The raw energy ... is exhilarating."-Ellen Frankfort

"The breadth of the anthology is extraordinary."-Publishers Weekly

424 pages

Cloth $\$ 10.00$, Paper $\$ 3.95$

(5.) THE WORLD OF THE BLUE COLLAR WORKER

Edited with an introduction by Irving Howe, editor of Dissent

"An anthology remarkable for its density and diversity ... a portrait in depth of the working class."-Norman Birnbaum, New York Times Book Review

316 pages

Cloth $\$ 8.95$, Paper $\$ 2.95$

(6.) WHAT YOU DON'T KNOW CAN HURT YOU

A Study in Public Opinion and Public Emotion

By Lester Markel, formerly Sunday editor of The New York Times

A provocative discussion and analysis of the basic elements of democracy, of the state of public information and public opinion, and of the urgent problem of enlightening the nation. "An impressive study..." -Robert Kirsch, Los Angeles Times

288 pages

Paper $\$ 2.95$

Examination policy: paperbacks are available on payment of $75 \phi$ service charge for postage and handling. Cloth books are available only at $10 \%$ discount and 30-day approval; if 10 or more copies are ordered, charge will be cancelled. Write directly to Quadrangle/The New York Times Book Co., 10 East 53rd Street, New York, N.Y. 10022. Distributed to the trade by Harper \& Row. 


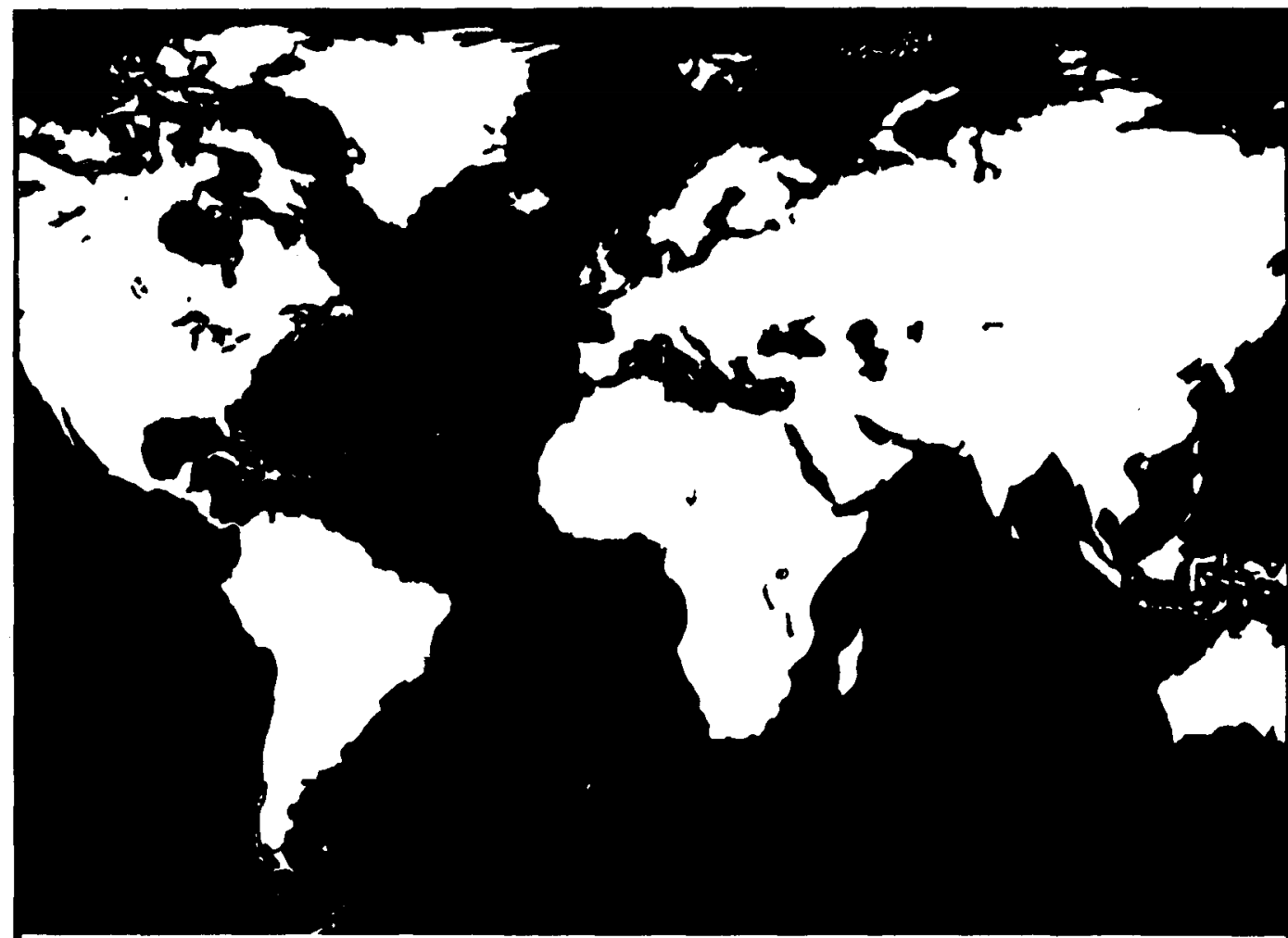

THE DEATH OF COMMUNAL LIBERTY

A History of Freedom in a Swiss Mountain Canton

BENJAMIN R. BARBER

For centuries the group of alpine villages that make up modern Canton Graubünden has managed to maintain its remarkable political tradition of direct democracy. But assimilation into the wider context of Switzerland and Europe has brought this tradition of communal liberty into violent conflict with the forces of modernization. Combining political theory and history, Benjamin Barber's multifaceted study traces the growth, maturity, and decline of a political and social life-style that may offer a communitarian alternative to the Anglo-American experience of representative government as an increasingly alienating and stifling

bureaucracy. $\$ 12.50$

\section{THE RULES OF RIOT}

Internal Conflict and the Law of War

JAMES E. BOND

Riots, insurrections, guerrilla movements, civil wars-all forms of internal conflict are increasing throughout the world. There are laws to protect human rights in peacetime and during international conflicts, but no body of law protects those caught up in civil strife. James $E$. Bond focuses on this major question: How can we regulate civil guerrilla warfare? "A fine piece of work on a critically important problem."-Richard A. Falk $\$ 11.50$

\section{PEOPLE'S CHINA AND INTERNATIONAL LAW}

\section{A Documentary Study}

JEROME ALAN COHEN and HUNGDAH CHIU

Professors Cohen and Chiu provide an extensive introduction, notes, and commentary to supplement this comprehensive study of the views of the People's Republic of China on all the major questions of public international law. The material chosen includes official acts and statements from every level of the Chinese government, the writings of Chinese scholars, and the speeches of China's leaders. Studies in East Asian Law, Harvard University 2 vols., $\$ 60.00$ 


\section{AFRICAN URBAN LIFE}

\section{The Transformation of Ouagadougou}

\section{ELLIOTT P. SKINNER}

Life in the capital of Upper Volta is being transformed by an influx of immigrants intent on entering the modern world. This study by the former U.S. Ambassador to the new republic discusses in rich detail all aspects of the town's life-highlighting basic problems and social processes that underlie much political unrest in rapidly urbanizing societies. $\$ 20.00$

\section{KENYA}

\section{The Politics of Participation and Control HENRY BIENEN}

Investigating positive elements in Kenya's party system and administration, ethnicity, and economic and class structure, Henry Bienen emphasizes the importance of local political networks. "Others have referred to the crisis of participation in developing lands but few have been as effective in analyzing it."-Donald Rothchild Written under the auspices of the Center of International Studies, Princeton University, and the Center of International Affairs, Harvard University $\$ 10.00$

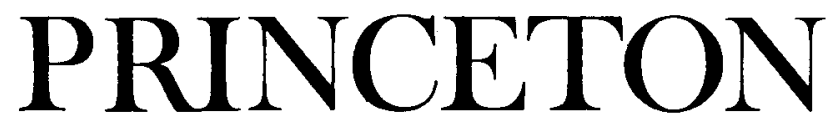

Now in paperback...

\section{THE NEW LEFT AND THE ORIGINS OF THE COLD WAR ROBERT JAMES MADDOX}

"Whatever one's explanation of the rise of New Left historiography, it seems abundantly clear that Maddox's volume has performed a great service. It marks a milestone in American historical writing since the Second World War."-The New York Times Book Review

Cloth, \$7.95; paper, $\$ 2.45$

\section{THE MILITARY IN POLITICS \\ Changing Patterns in Brazil \\ ALFRED STEPAN}

"This book's contributions are both substantive and methodological, and it should serve as a point of departure for comparable studies in other countries. Stepan's The Military in Politics is probably the best study we have of civil-military relations in a poor country."-Robert A. Packenham, American Political Science Review Cloth, $\$ 12.50$; paper, $\$ 3.45$

\section{DILEMMAS OF GROWTH IN PREWAR JAPAN}

\section{Edited by JAMES W. MORLEY}

"Despite the usual difficulty in organizing mutually sustaining papers with continuity, this work is extremely well designed and of reasonably even quality scholarship."-Perspective Studies in the Modernization of Japan Cloth, \$12.50; paper, \$3.95

\section{CRISES AND SEQUENCES IN POLITICAL DEVELOPMENT}

Contributions by Leonard Binder, James S. Coleman, Joseph LaPalombara, Lucian W. Pye, Sidney Verba, Myron Weiner

"A major contribution to the series .... a very important and readable source for advanced undergraduate collections."-Choice

Studies in Political Development, 7

Cloth, $\$ 12.50$; paper, $\$ 3.95$

Write for Political Science catalogue

PRINCETON UNIVERSITY PRESS

Princeton, New Jersey 08540 


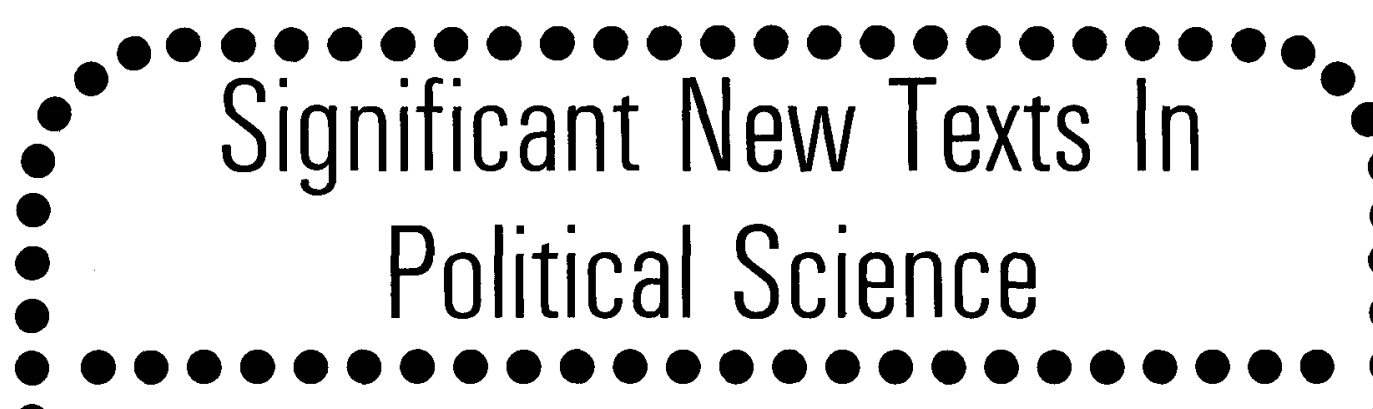

MAJOR EUROPEAN GOVERNMENTS, Fourth Edition

Alex N. Dragnich, Vanderbilt University and Jorgen Scolt Rasmussen, lowa State University

Offering an explanatory approach drawing on fundamental concerns in political science, this popular basic text for courses in European governments or comparative government has been updated in all essentials. The four country sections (Great Britain, France, Germany, and the Soviet Union) have been rewritten extensively, and graphic material is utilized as an intrinsic part of the book. The outstanding advantage of the book is that it will encourage meaningful, insightful discussion among students and with instructors.

- POLITICS AND THE COMMON MAN:

- An Introduction to Political Behavior

H.T. Reynolds, University of Delaware

- Describes and interprets the political attitudes and behavior of the common man. Focuses on political life from conventional politics to participation in mass movements and violence.

Paperbound

\section{PUBLIC OPINION AND PUBLIC POLICY:}

Models of Political Linkage, Revised Edition

Norman R. Luttbeg, Florida State University

This new edition retains the organization which proved so helpful in the first edition, but better than half of the 27 selections are new. These new studies draw on the continuous study of Presidential elections since 1952, capturing trends in the American electorate.

Paperbound

\section{THE EVOLUTION OF SOVIET POLITICS}

Robert J. Osborn, Temple University

An introduction to the Soviet political system presented as an interpretation of its evolution from 1917 to the present, and focusing on certain features of the Tsarist system it replaced. The text discusses the major decisions that shaped the system as it exists today, from the Revolution up to the most recent decisions.

Examination copies for adoption consideration available on request; please indicate course title and text presently used.
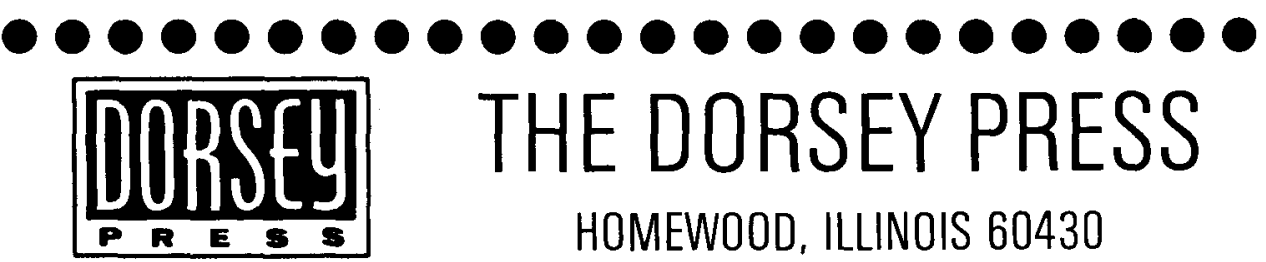

DORSEY PR

HOMEWOOD, ILLINOIS 60430

Write for our complete 1974 Catalog 


\section{fromTemple}

Reflections on the Cold War

A Quarter Century of American Foreign Policy

Edited by Lynn H. Miller and Ronald W. Pruessen

Leading American political scientists, historians, and commentators-among them, Harrison Salisbury, Richard Falk, and Stanley Hoffman-here present a balanced perspective on the Cold War that draws on memoirs and policy documents from the forties, fifties, and sixties that only recently became available. "An authoritative, well-balanced assessment of U.S. foreign policy since the end of the Second World War."-Hans J. Morgenthau $\$ 10.00$

\section{The Politics of Massacre}

\section{Political Processes in South Vietnam}

Charles A. Joiner

A recognized authority analyzes the important role of South Vietnamese politics in the Indochina War, considering the impact of external powers and placing Vietnam's political factionalism in the historical context so necessary to an understanding of any future elections in South Vietnam. Prof. Joiner indicates the course that the government of South Vietnam is likely to take, and considers to what extent Vietnamese unification will be possible. $\$ 12.50$

\section{The Challenge of Urban Reform}

\section{Policies and Programs in Philadelphia}

Kirk R. Petshek

\section{Foreword by Martin Meyerson}

Formerly city economist of Philadelphia, Prof. Petshek brings an insider's understanding to the city's surprising reform government of the fifties and sixties under Mayors Clark and Dilworth. Of special interest to politically alert citizens and specialists in urban affairs, this candid and comprehensive study of the reform and its remarkable policy-making methods includes detailed case histories of specific developmental programs. $\$ 10.00$

\section{The Politics of Belleville}

\section{A Profile of the Civil Community Daniel J. Elazar}

Taking Belleville, Illinois, as an example, Prof. Elazar has investigated the political culture of the medium-sized American city-a civil subdivision that has been largely ignored by scholars. Outlining the structure of the community as a whole and its patterns of political behavior, he shows how a vast array of public and private institutions has affected power relationships, political cleavages, and the public policy of the community. $\$ 8.50$ 


\section{Spring 1974}

THE AMERICAN DEMOCRATIC SYSTEM

By J. KeITH MELviLLE, Brigham Young University

Paperback.368pp. $\$ 4.95$

\section{BLACK CITY POLITICS}

By ERnest Patterson, University of Colorado

Paperback. 298 pp. $\$ 5.95$

THE AMERICAN JUDICIAL PROCESS: Models and Approaches

By CHARLES H. SHELDON, Washington State University

Paperback. 232 pp. $\$ 5.95$

\section{THE PHENOMENON OF REVOLUTION}

By Mark N. HaGopian, American International College

Paperback.416 pp. $\$ 6.95$

\section{Publications}

AMERICAN DEFENSE AND DÉTENTE: Readings in National Security Policy

Edited by Eugene J. Rosı, Dickinson College Cloth. 532 pp. $\$ 5.95$

NATO: The Dynamics of Alliance in the Postwar World By EDWIN H. FEDDER, University of Missouri at St. Louis

Paperback. 155 pp. $\$ 3.95$

THE POLITICAL SYSTEM OF COMMUNISM

By Richard C. Gripp, California State University, San Diego Paperback. 224 pp. $\$ 3.95$

POLLUTION AND PUBLIC POLICY: A Book of Readings

Edited by David F. Paulsen, University of North Dakota, and Robert B. Denhardt, Louisiana State University in New Orleans Paperback. 258 pp. $\$ 4.95$

DODD, MEAD \& COMPANY

79 Madison Avenue, New York, N.Y. 10016 

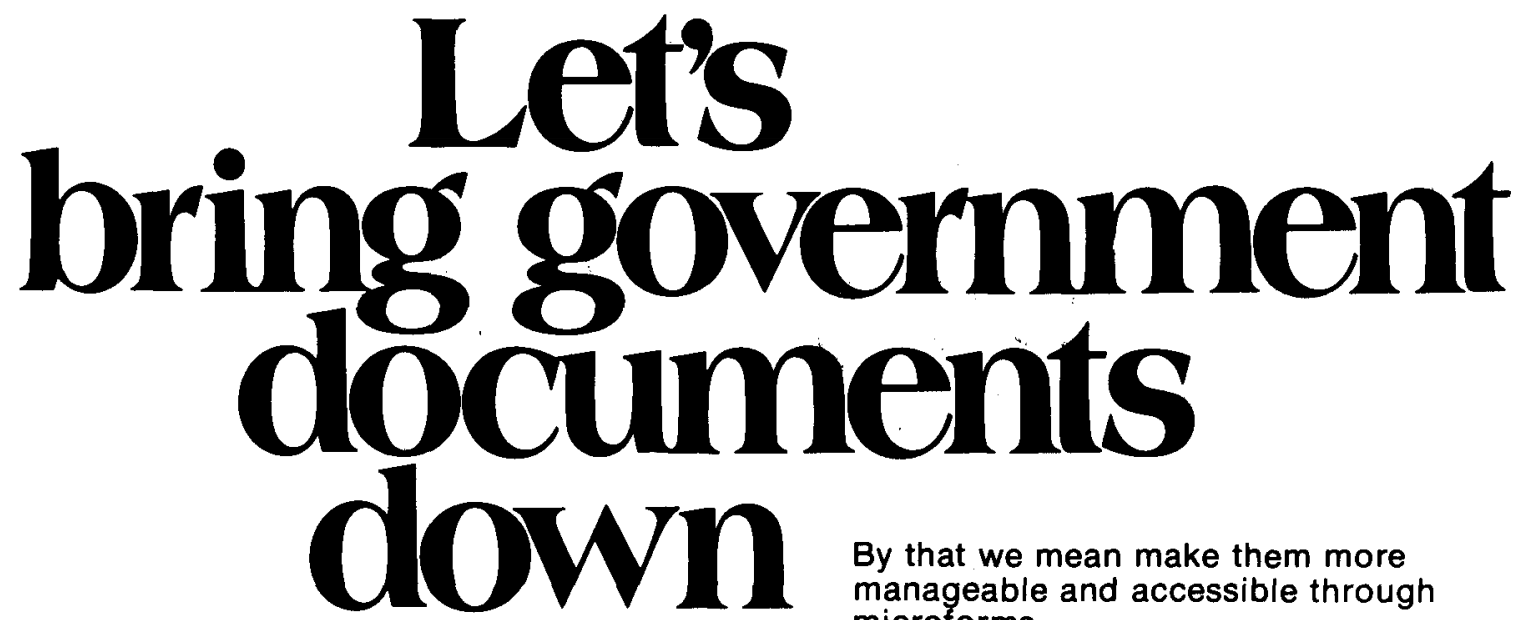

By that we mean make them more manageable and accessible through microforms.

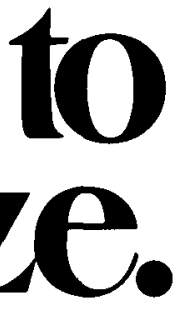

Take, for example, the new subscription service we offer for THE CONGRESSIONAL RECORD. For the first time, you can subscribe to both a Monthly Index and Guide to the Congressional Record, plus issues of the RECORD on microfiche. The comprehensive and easy-to-use hard-copy Monthly Index makes information in the RECORD more accessible than ever before. And timely, too, because both the index and the microfiche are shipped within 10 days of the month covered.

Our collection includes thousands of other government documents, many of them out-of-print or difficult-to-obtain. Among these are The Catalog of United States Census Publications, 1820-1945 ... all Congressional Hearings from 1839 through the 83rd Congress of 1954 ... The Annals of Congress covering the proceedings of the 1st through 18th Congresses, 1789-1824 ... Session Laws for all the states and territories prior to $1900 \ldots$ and The Monthly Labor Review, 1915-1972.

What's more, we offer many nongovernmental source materials about government. These include a tape cassette series on the Structure and Function of American Government, plus thousands of doctoral dissertations covering all aspects of government, its history and actions.

How do we size up in relation to your needs? To get a better idea, write to our Literature Services Department and ask for information about the types of documents or materials you're interested in. You'll receive full details. 


\section{Political Conflict}

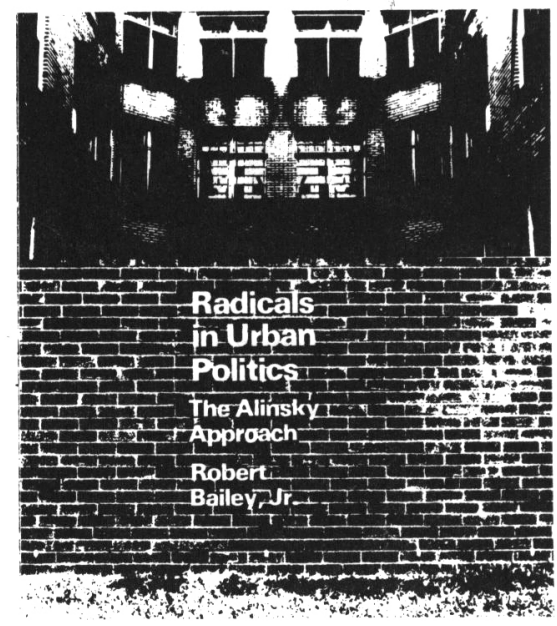

For more than thirty-five years the late Saul Alinsky taught impoverished and powerless urban residents how to use conflict and disruption to force authorities to make concessions. Robert Bailey, Jr., offers the first analysis of the Alinsky methods and philosophy, which are now being carried on by other professional organizers.

1974208 pages illus. Cloth $\$ 9.95$

\section{The Nehrus \\ Motilal and Jawaharlal \\ B. R. Nanda}

Based largely upon unpublished sources, including the Nehru family papers, this twin biography of Pandit Motilal Nehru and his son Prime Minister Nehru also contains a coherent, incisive, and gripping survey of seventy years of Indian history from 1861 to 1931. The evolution of Jawaharlal as the champion of an independent and socialist India, and the political clashes as well as the emotional bonds between father and son are graphically described.

\section{4 pages Paper $\$ 3.95$ \\ Urban Policy and Political Conflict in Africa \\ A Study of the Ivory Coast \\ Michael A. Cohen}

In this public policy study, Michael $A$. Cohen analyzes the consequences of the Ivory Coast's "state capitalist" approach to its development problems. He examines the relationship between urban policy, urban resource distribution, social stratification, and political conflict in the Ivory Coast during 1969-70.

1974288 pages Cloth $\$ 14.75$

\section{The University of Chicago Press}

\section{Chicago 60637}




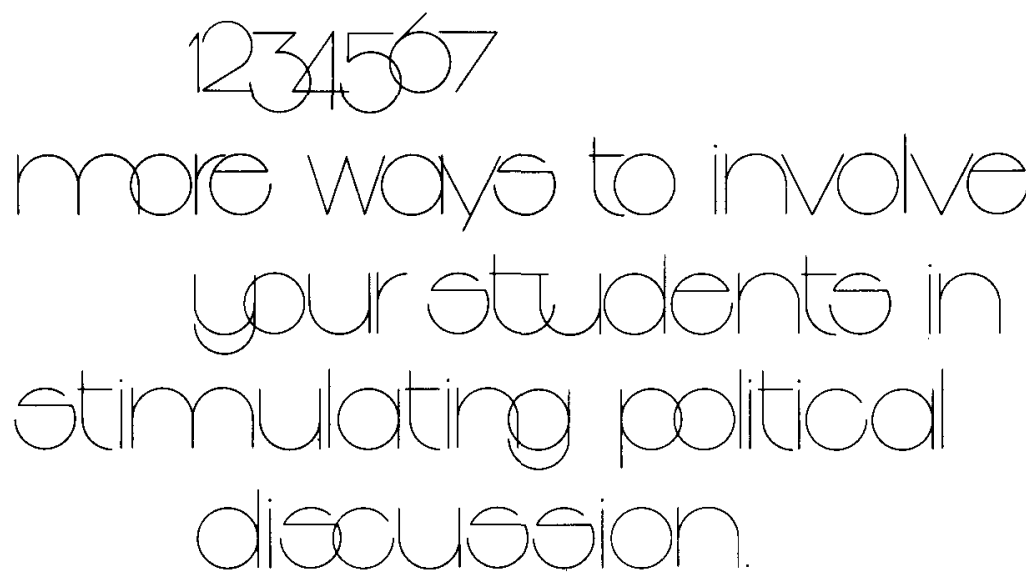

Quantitative Analysis of Political Data by Samuel A. Kirkpatrick, University of Oklahoma, discusses a broad range of contemporary quantitative analysis techniques. The book goes further in aiding the student to grasp all the details of the research process than other books of its kind.

The text material familiarizes the student with techniques-inuse; the readings help the student understand the entire research process. 1974/528 pages $/ 6 \%$ x $\times 9 \% 4^{\prime \prime} / \$ 15.95 / \# 8903$
Foreign Policy Analysis: A Comparative and Conceptual Approach by Howard H. Lentner, The City University of New York, provides a coherent framework for analyzing foreign policy. The comprehensive coverage treats the states, international organizations, and transnational actors, the settings in which they behave, and their relationships. $1974 / 304$ pages $/ 6 \times 9 " / \$ 9.95 / \# 8884$

Concepts of Politics: A Working Book in American National Government by John Ramsey, Old Dominion University, provides a solid framework and concentrates the student's attention on the large, critical ideas in American politics. The book maximizes the teacher's role as motivator and manager of the learning process. 1974/ 208 pages $/ 81 / 2 \times 11^{\prime \prime} / \$ 5.95$ softbound/ $\# 8941$
The Ideologies of Violence by Kenneth W. Grundy, Case Western Reserve University, and Michael A. Weinstein, Purdue University, systematically analyzes the term "violence" as used in political ideology. The authors unite theoretical analysis and diverse examples from contemporary and historical public affairs to provide a critical survey of the major justifications for political violence. 1974/128 pages/ $6 \times 9^{\prime \prime} / \$ 2.95$ softbound/ $/ 8835$

Truth and Meaning in Political Science: An Introduction to Political Inquiry by Maria J. Falco, Le Moyne College, orients the beginning student to the rationale of research methodology. The book answers such basic questions as how political science became a social science discipline, what it means to be a political scientist, and what the scientific method implies. 1973/136 pages $/ 6 \times 9^{\prime \prime} / \$ 2.95$ softbound/ \#8934
American State and Local Government by John Straayer, Colorado State University, gives the student a sound introduction to the structure and process of state and local government. The author aims to provide students with a continuing understanding of the relationship of governmental processes to their daily lives. $1973 / 320$ pages $/ 6 \times 9^{\prime \prime} / \$ 5.95$ softbound/\#8995
Comparative Politics: The Quest for Theory by James A. Bill and Robert L. Hardgrave, Jr., both, University of Texas at Austin, introduces students to recognizing and evaluating basic approaches to comparative political analysis. The authors draw from the experience of non-western and western societies. $1973 / 256$ pages/ $6 \times 9 " 1$ (\$4.95 softbound/ \#9008 


\section{REGICIDE AND REVOLUTION}

Speeches at the Trial of Louis XVI

MICHAEL WALZER

Professor of Government, Harvard University

This book raises questions about what constitutes justice when the conduct of the highest officials is at issue. The author uses the trial as his model and introduces eleven speeches by Marat, Robespierre, Saint-Just and others which test the theory of royal immunity. His accompanying essay comments on the debate and sets forth a moral argument in defense of the trial and execution.

$\$ 12.50$

\section{THE POLITICAL TRANSFORMATION OF THE BRAZILIAN CATHOLIC CHURCH}

\section{THOMAS C. BRUNEAU}

An institutional and historical analysis of the Brazilian Catholic Church since the colonial era, focusing in particular on its political role in relation to the state and society.

Cloth $\$ 16.50$ Paper $\$ 6.95$

\section{HITLER'S STRATEGY 1940-1941}

The Balkan Clue

MARTIN L. VAN CREVELD

Did Mussolini invade Greece against Hitler's wishes? Were the Fuhrer's plans for that country purely defensive? What effect did Germany's campaign in the Balkans have on her attack on Soviet Russia? This study, utilizing numerous unpublished sources, proposes answers that may well necessitate revision of the established writings on Hitler's foreign policy and military strategy.

$\$ 13.95$

\section{THE WARSAW RISING OF 1944}

\section{JAN M. CIECHANOWSKI}

This detailed account, based on Polish contemporary documents and interviews with participants of the Warsaw Rising, examines the political, diplomatic, ideological and military background of the Rising and the events and decisions which preceded it.

$\$ 19.50$

\section{COLONIALISM IN AFRICA 1870-1960}

Volume 5: A Bibliographical Guide to

Colonialism in Sub-Saharan Africa

Edited by PETER DUIGNAN and L. H. GANN

A reference tool covering the literature from about 1870 to 1960 .

$\$ 27.50$

Previously published:

Volume 1: The History and Politics of Colonialism 1870-1914

$\$ 19.50$

Volume 2: The History and Politics of Colonialism 1914-1960

$\$ 19.50$

Volume 3: Profiles of Change: African Society and

Colonial Rule (Edited by Victor Turner)

$\$ 19.50$

\section{DEPENDENCE AND OPPORTUNITY}

\section{Political Change in Ahafo}

JOHN DUNN and A. F. ROBERTSON

A study of the historical relationship between the system of British colonial control and local socio-political structure, showing the impact of colonialism on government particularly and also on medicine and education.

$\$ 19.50$

\section{Cambridge University Press}




\section{How Family Members Perceive Each Other}

\section{Political and Social Attitudes in Two Generations}

\section{Richard G. Niemi}

$\therefore$ In the basis of interviews with I 669 high school seniors and their parents on a number of topics, mostly relating to politics, Richard Niemi finds that family members show a wide variation in levels of accuracy in reporting on each other's values, attitudes, characteristics, and behavior. His findings substantially undermine or qualify much of the information about the family gathered in earlier studies in which only one member of the family was interviewed. $\quad \$ 10.00$

\section{Disaster and the Millennium}

Michael Barkun

In this absorbing study, Michael Barkun develops the original thesis that millenarian movements are consequences of local disasters. He presents many examples of millenarian groups in action in both modern and primitive societies, reviews existing theories and explanations, and speculates about the future of millenarianism in the modern world.

"The best general study of millenarian movements from the social-scientific point of view."-Jeffrey B. Russell \$10.00

\section{Modern Social Politics in Britain and Sweden}

\section{From Relief to Income Maintenance}

\section{Hugh Heclo}

How has politics affected the advent and extension of modern social policy? What have been the respective roles of socioeconomic development, suffrage changes, party competition, interest group pressures, and administrative influences?

This book seeks to answer these questions by tracing the evolution of key income maintenance policies (unemployment benefits, basic pensions, and earningsrelated pensions) in Britain and Sweden. The focus is on "social politics": the challenge of coping politically with social conditions and needs. $\quad$ \$ 5.00

Now available in a paperbound edition

\section{Regimes and Oppositions}

Robert A. Dahl, editor $\$ 3.95$

\section{Yale University Press New Haven and London}


"... there is not a scintilla of evidence in the constitutional records... to authorize executive withholding of any information from Congress." page 59.

"The Nixonian rationale for his freshly minted claims of privilege again illustrates that the appetite for power grows by what it feeds on." page 255.

"The steady expansion of executive privilege ... imperils our democratic system. It is therefore the concern of everyman." page 372.

\section{Raoul Berger, author of Impeachment, has written a new book: Executive Privilege: A Constitutional Myth $\$ 14.95$}

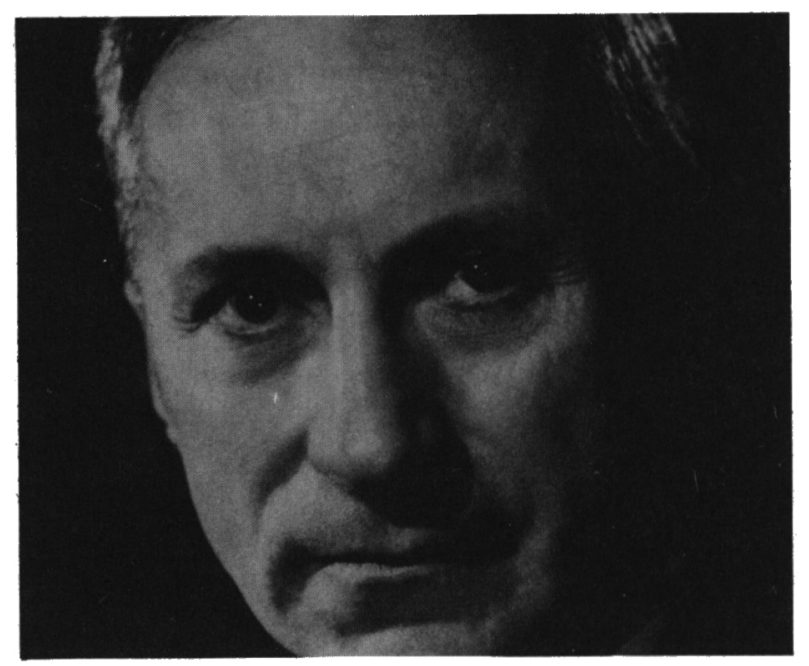

“Raoul Berger's study of executive privilege is a rich and masterly work of historical research and argument, penetrating to the heart of the great issues of presidential power." Arthur Schlesinger, /r.

\section{Studies in Legal History}

\section{Harvard University Press}

Cambridge, Mass. 02138

Impeachment: The Constitutional Problems.

Available in cloth: \$14.95, paper: \$3.95. 


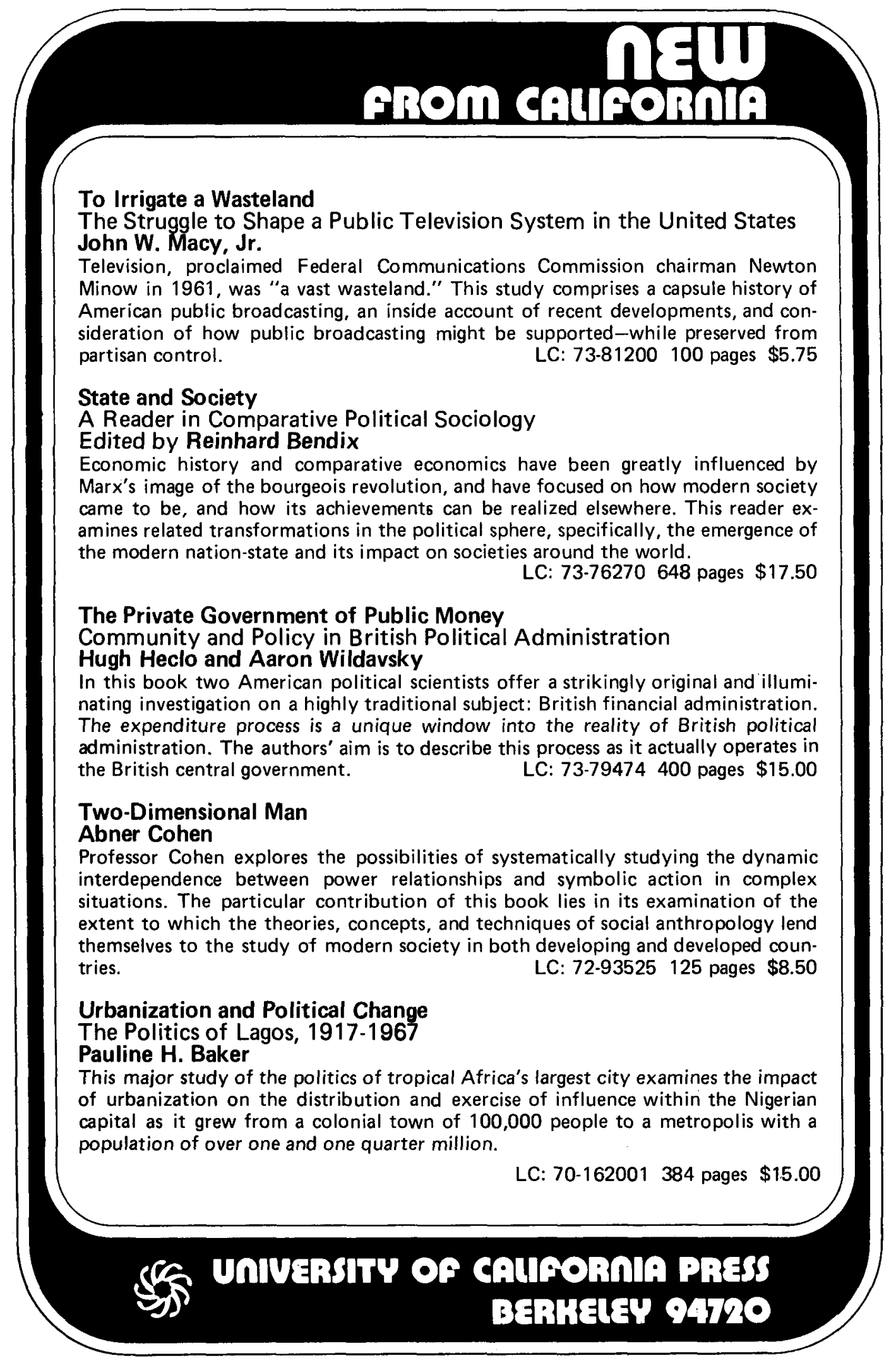




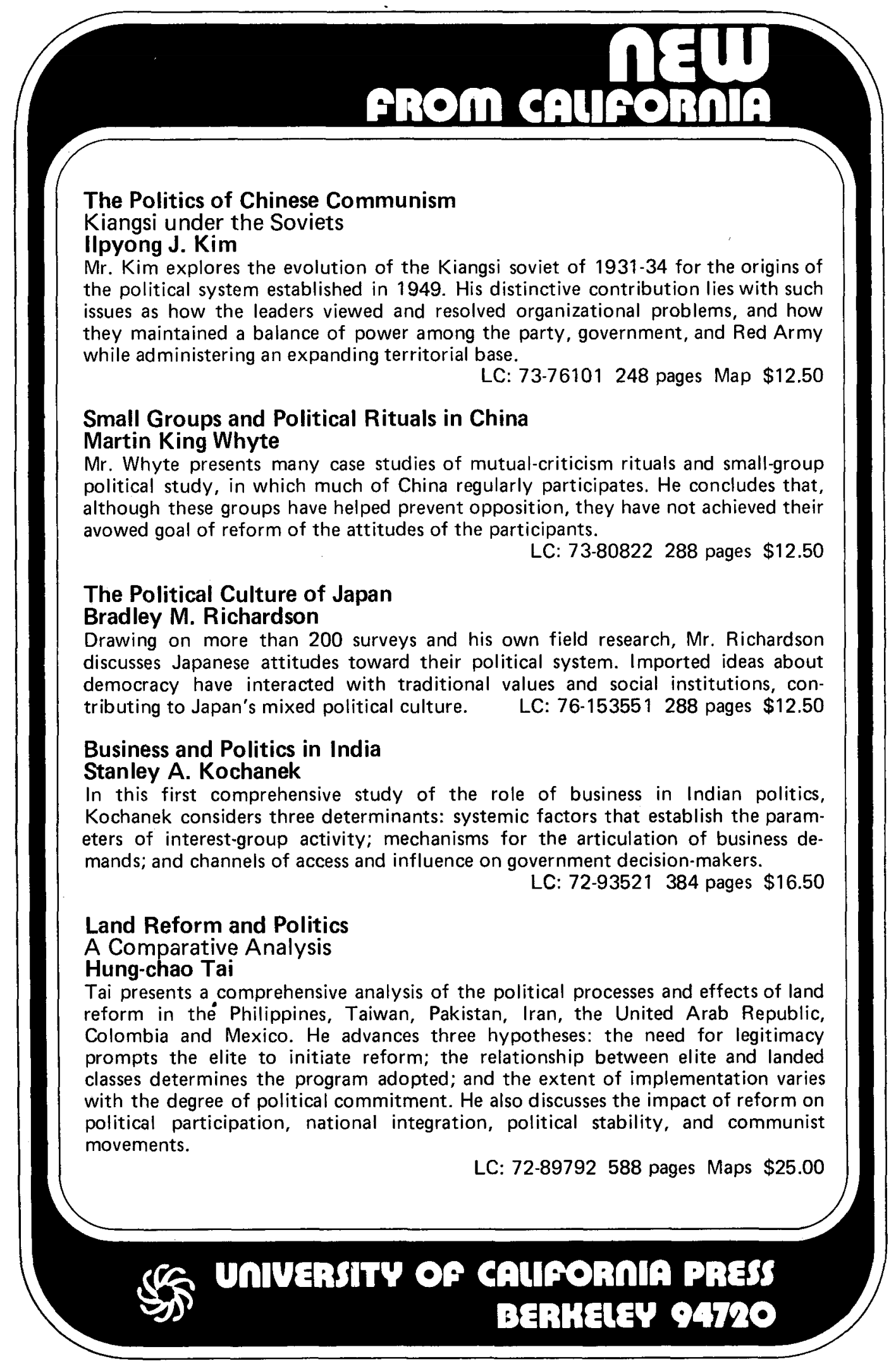




\section{srom ciusomin}

Empire and Liberty

American Resistance to British Authority, 1755-1763

Alan Rogers

In the course of the 18th century Americans assimilated a radical political persuasion: a fear of power and a deep concern for liberty were its central tenets. Rogers contends that this world view was due not to political paranoia, but to the colonists' experience during the Great War for Empire, when Americans from every social class learned to fear the use of arbitrary powers by the British generals.

LC: $72-82225256$ pages $\$ 10.00$

\section{The Young Lloyd George \\ John Grigg}

Mr. Grigg was the first biographer to be allowed to use the magnificent collection of Lloyd George's early letters and documents which came to light a few years ago. These provide a vivid picture of Lloyd George from his birth in 1863 to 1902. This new interpretation of the man, both as a private individual and as a major historical personality, is indispensable reading for anyone interested in modern British history.

LC: $73-91067320$ pages 30 illustrations $\$ 12.00$

\section{Church, State and Opposition in the U.S.S.R.}

\section{Gerhard Simon}

The churches are a fringe phenomenon in Soviet society today, but nevertheless one that is taken seriously by the atheist state. Dr. Gerhard Simon, one of the world's outstanding authorities on religion in Russia, examines church-state relations and religious persecution from the time of the revolution to the present.

LC: $73-87754248$ pages $\$ 12.00$

\section{Winner of the 1974 Anisfield-Wolf Award in Race Relations Justice in South Africa, by Albie Sachs Cloth, \$9.00; Paper, \$3.25}

\section{NOW AVAILABLE IN PAPERBACK}

Mao's Way

Edward E. Rice

\section{Systems Analysis in Public Policy \\ A Critique \\ Ida R. Hoos}

Pornography and Sexual Deviance Michael J. Goldstein and Harold S. Kant with John J. Hartman
The Politics of Cultural Despair

A Study in the Rise of the Germanic Ideology

Fritz R. Stern

The Unwelcome Immigrant

The American Image of the Chinese, 1785-1882

Stuart C. Miller 
NUCLEAR THEFT: RISKS AND SAFEGUARDS

Mason Willrich, University of Virginia, and Theodore B. Taylor, International Research and Technology Corporation

Analyzes the possibility of nuclear blackmail and coercion by diverting materials from the nuclear power industry in the United States. Finds that the present system of safeguard requirements is woefully inadequate. It recommends substantial changes in current policy and makes concrete suggestions for a system based on prevention. It is designed to contribute to public understanding of the technical facts and policy issues in this critical area of energy. A Ford Foundation Energy Policy Project Study.

0-88410-207-6 (cloth) $256 \mathrm{pp}$. April $\$ 13.50$

0-88410-208-4 (paper) \$ 4.95

THE REHABI LITATION POTENTIAL OF WESTERN COAL LANDS

National Academy of Sciences and National Academy of Engineering

Analyzes in detail the vast and complex problem of rehabilitating strip mined coal lands of the west. Finds that in some areas rehabilitation would be almost impossible, and suggests that energy distribution networks may be a greater threat to the ecology than actual mining sites. Recommends more effective mining laws, urges further research on methods of land rehabilitation, and more awareness of the hazardous trade-offs involved in mining western lands. A Ford Foundation Energy Policy Project Study.

0-88410-331-5 (cloth) $144 \mathrm{pp}$. May $\$ 8.50$

0-88410-347-1 (paper) \$2.95

OIL SPILLS AND THE MARINE ENVIRONMENT

Donald F. Boesch, Carl H. Hershner, University of Virginia, and Jerome H. Milgram, MIT

Two papers are combined to assess both the ecological and technological aspects of oil pollution, and bring together and overview of current knowledge about the effects of oil spills and the efficiency of preventive safeguards. A Ford Foundation Energy Policy Project Study.

$0-88410-310-2$ (cloth) $\$ 7.00$

0-88410-326-9 (paper) 112 pp. July $\$ 2.50$

METROPOLITAN WATER MANAGEMENT: NATIONAL POLICY IMPLICATIONS Marc Roberts and Michael Hanemann, Harvard University, and Bert Collins, Urban Systems Research \& Engineering, Inc.

Examines the planning, decision-making and implementation practices used in urban water management in several metropolitan areas including Boston, Seattle, and Milwaukee. Makes specific recommendations for federal action to improve financing, personnel practices, operations, availability of data, analyses, and the institutional and legal framework of water planning decision-making. 0-88410-305-6 $190 \mathrm{pp}$. June $\$ 12.50$

THE PRESIDENT'S TASK FORCE REPORT ON SUBURBAN PROBLEMS edited by Charles $M$. Haar, Harvard University

Foreword by Senator Edward M. Kennedy

A distinguished group of policymakers makes specific recommendations for policy leadership, programmatic and financial responsibility which the Federal Government should assume in order to address the problems of suburbs and suburban dwellers. $0-88410-019-7256$ pp. May $\$ 12.50$

CITIZEN ATTITUDES TOWARD LOCAL GOVERNMENT, SERVICES AND TAXES Floyd J. Fowler, Survey Research Program, University of Massachusetts and Joint Center for Urban Studies of MIT and Harvard University

Reports results from 4300 interviews taken with cross-section samples of adults in ten major American cities, who were asked about their views and feelings on city government, city services and city problems. The book constitutes an unparallelled resource for understanding the extent to which patterns of citizen satisfaction within cities are similar, or in fact differ with the community context. $\quad 0-88410-408-7 \quad 180 \mathrm{pp}$. July $\$ 12.50$ 


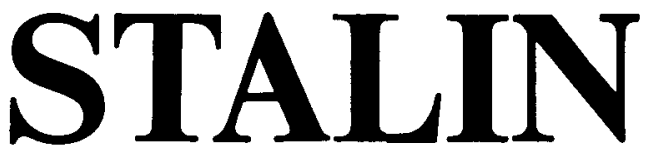

AS REVOLUTIONARY, 1879.1929

A Study in History and Personality

By ROBERT C. TUCKER. "Amply documented with full indication of sources, judicious and careful where there is temptation to sensationalize, it is the most detailed biography yet to appear. ... Over such outstanding predecessors

as Boris Souvarine, Louis Fischer, and Isaac

Deutscher, Tucker has the advantage of a mass of new information released by de-Stalinization and the growth of Samizdat. . . . More important

is Tucker's effort to analyze and make understandable Stalin's enigmatic character. . . . Tucker offers many interesting facts and suggestive theories; his effort to elucidate the murky figure of Stalin may well remain the best until some researcher is able to pore through the Kremlin archives."-Robert G. Wesson, Political Science Quarterly • Norton Library Edition Paper, \$3.95 - Coming in August

THE ANGUISH OF CHANGE

By LOUIS HARRIS. "A first-rate study on America's traumatic evolution of the last two decades.... Harris' work, based mainly on the research of his organization, is a study of how the people have perceived and reacted to the new order. . . A well-written and authoritative study." -Library Journal. "A sharp and persuasive estimate of crucial social changes."-New Yorker

Paper, $\$ 2.95$

\section{THE FUTURE WHILE IT HAPPENED}

By SAMUEL LUBELL. "A useful synthesis of 1972 voter attitudes in the context of the politically ruthless force that helped shape them. For those who may think all the heavy-handedness of 1972 occurred in the burglary and dirty tricks departments, this analysis of the Nixon mobilization of issues and the incumbent's power to shape them, for now and the future, is instructive." -JUles Witcover, Washington Post Book World

Paper, $\$ 1.95$ 


\section{New in African Politics}

\section{THE COLONIAL REVOLUTION}

By Fenner Brockway

An authoritative look at the struggles for national independence in the 20th century, covering the anti-colonialist movements in Africa, Asia, Europe, Latin America, and the Middle East. Includes a valuable list of territories acquired by the various world empires, the method of occupation, and the territory's current status.

September $\quad 650$ pages $\$ 23.95$

\section{PEASANT POLITICS:}

\section{Conflict and Development in Murang'a}

By Geoff Lamb

Focuses on the workings of a single local government district in Kenya, showing how plans for political and social development at the national level are translated, sidetracked, slowed, or ignored.

September $\quad 172$ pages $\$ 10.95$

\section{PRESIDENTIALISM IN COMMONWEALTH AFRICA}

By B. O. Nwabueze

One of Africa's leading legal scholars analyzes the formal structure of one-party government in Commonwealth Africa. He relates the trend toward powerful central government to the need for social and economic development, and assesses the moves toward less centralized forms of rule.

September $\quad 480$ pages $\quad \$ 25.00$

\section{ZAMBIA: Security and Conflict, 1964-1973}

By Jan Pettman

Focuses on the search for internal and external security in Zambia-a nation of critical importance in the conflicts between black and white Africa. Describes the country's political and economic development and Zambia's efforts to find allies and foreign aid.

September $\quad 381$ pages $\$ \mathbf{\$ 1 3 . 9 5}$

\section{SOUTH AFRICA: Economic Growth and Political Change}

Edited by Adrian Leftwich

The essays in this book examine whether and how economic development will act to alter prevailing political, social, and racial relationships in South Africa. Also provides valuable comparative information on growth and change in Ceylon, Malaysia, and Chile.

September 344 pages $\$ 12.95$

\section{ACCELERATED DEVELOPMENT IN SOUTHERN AFRICA}

Edited by John Barratt, Simon Brand, David S. Collier, and Kurt Glaser

More than 50 contributors from the U.S., Europe, and eight African states consider ways to accelerate the political, social, and economic development of countries in the southern part of Africa. Commentaries following the major articles often reflect differing viewpoints, and three essays on various aspects of development conclude the volume.

September $\quad 640$ pages $\quad \$ 16.95$ 


\section{New in British Politics}

\section{POLITICAL CHANGE IN BRITAIN, Second Edition}

By David Butler and Donald Stokes

A thorough revision of a landmark study of voting behavior, party loyalty, and issues and ideologies. For the Second Edition, the authors have re-interviewed many of the same voters they surveyed in the mid-1960s for their first edition. With this new data, taken in a time of Labour rather than Conservative power, the authors make a more long-term assessment of stability and change in the electorate. New in the Second Edition are discussions of the decline of social class as a basis for party loyalty, and the effects of a huge influx of immigrants on the electorate as a whole.

October $\quad 400$ pages $\$ 17.95$

\section{FRONT-BENCH OPPOSITION: \\ The Role of the Leader of the Opposition, the Shadow Cabinet, and Shadow Government in British Politics}

By R. M. Punnett

An important reference for all concerned with the study of British government and Parliamentary politics. Heavily illustrated with charts and tables, Front-Bench Opposition examines the merits and faults of Britain's "shadow government" system, covering the history of the opposition, the functions of opposition party members, and the transition from opposition to office.

1973508 pages $\$ 17.95$

\section{BY-ELECTIONS IN BRITISH POLITICS}

By Chris Cook and John Ramsden; with an introductory chapter by David Butler

Original and extremely topical, this book brings together contributions from specialists in many different fields, and includes a valuable statistical analysis of by-elections since 1918 .

January 224 pages $\$ 17.95$

\section{THE CONSERVATIVE PARTY, 1918-1970}

By T. F. Lindsay and Michael Harrington

The first history of the modern British Conservative Party. Studies party policy and organization and the fortunes of individual Conservatives in relation to the party.

April $\quad 300$ pages $\$ 15.95$

\section{ANGLO-AMERICAN RELATIONS SINCE THE SECOND WORLD WAR}

By lan McDonald

A concise, lucid account of the changes and strains in the British-American political relationship from World War II to the present. The author traces the beginnings of the "special relationship" between the two countries during the war in Europe, Britain's decline as a world power, and the beginning of a "natural relationship" as Britain turned away from the U.S. and toward Europe and the Common Market.

October 248 pages $\$ 12.95$ 


\section{New in European Politics}

\section{THE POLITICS OF FOREIGN AID}

By John White

An important new look at the political and economic impact of foreign aid. The author points out many of the shortcomings of foreign aid and covers the history and current participants in foreign aid programs. He weighs the traditional moral arguments for aid against the more realistic political and economic reasons why aid is offered and accepted.

July 320 pages $\$ 13.95$

\section{THE DEFENSE OF WESTERN EUROPE}

Edited by John C. Garnett

Defense officials and political scientists look to the future of European defense and mutual security in the emerging era of detente and the Nixon Doctrine. The contributors discuss the military problems of NATO, the defense problems of the Common Market countries, the effects of American and Soviet policy, and European collaboration in weapons procurement.

February 250 pages $\$ \mathbf{\$ 1 2 . 9 5}$

\section{SOCIAL DEMOCRACY IN POSTWAR EUROPE}

By W. E. Paterson and I. R. Campbell

This succinct volume defines Social Democracy and traces its history from World War II to the present, considering Socialist ideology and the party's relations with the Catholic Church, trade unions, and the Communists and other leftist parties.

January 96 pages $\$ 6.95$

\section{INTERNATIONAL DISPUTES:}

\section{The Political Aspects}

By F. S. Northedge and M. D. Donelan

Studies 50 international disputes that occurred between 1945 and 1970, considering their origin, development, and solutions. The authors ask how disputes arise, how can they be distinguished, and why some disputes are settled peaceably and others by force.

$1972 \quad 348$ pages $\$ 12.95$

\section{INTERNATIONAL DISPUTES: \\ Case Histories, 1945-1970}

By M. D. Donelan and M. J. Grieve

Short chronologies of the $\mathbf{5 0}$ international disputes discussed in detail in International Disputes:

The Political Aspects, described above.

1973280 pages $\$ 12.95$

\section{EUROPEAN POLITICAL FACTS, 1918-1972}

By Christopher Cook and John Paxton

This is an essential reference that contains all of the most important political, social, and economic facts for 35 European countries. The book covers international organization membership, government and political systems, justice, treaties, population trends, economic policy; and education and the press.

1973 400 pages $\$ 14.95$

\section{St. Martin's Press}




\section{New in International Politics and Modern Ideologies}

\section{THE CANBERRA MODEL: \\ Essays on Australian Central Government}

By David E. Butler

One of Britain's foremost authorities on electoral politics focuses on the workings of the Australian government-a system that is of great interest to students of comparative government. He discusses the relations of ministers and civil servants, the role of the Prime Minister, ministerial responsibility, and government secrecy.

March 160 pages $\$ 15.95$

\section{ALLENDE'S CHILE}

Edited by Kenneth Medhurst

Eight Chileans-including two former members of the Allende government-examine the volatile Marxist-Leninist rule of Salvadore Allende. This timely book details the forces at work in modern Chilean politics and offers valuable insights into the causes behind the bloody 1973 coup that ousted Allende.
1973
212 pages
$\$ 8.95$

\section{POLITICS IN SRI LANKA, 1947-1973}

By A. Jeyaratnam Wilson

A well-known Ceylonese political scientist examines the political and social factors behind 25 years of peaceful democratic rule in his country. He considers the interrelationships between the island's various cultural and ethnic groups, the progress of Ceylon's economy, and political change and constitutional development. He also discusses the effects of colonial rule and the continuing Western presence on his country's political, economic, and social affairs. March 350 pages $\$ 18.95$

\section{KNOWLEDGE AND BELIEF IN POLITICS: The Problems of Ideology}

Edited by Robert Benewick, R. N. Berki, and Bhikhu Parekh

These essays analyze some general philosophical problems encountered in the study of ideology, discuss specific ideologies, and cover the role of ideologies in holding together a society and shaping domestic and foreign policies. The contributors assess the relationship between ideology and social science, ideology and economic development, and politics and ideology.

$1973 \quad 327$ pages $\$ 14.95$ 


\section{The Definitive \\ Bibliography}

\section{from The American Library Association}

\section{THE ALLIED OCCUPATION OF JAPAN, 1945-1952}

An Annotated Bibliography of Western-Language Materials

by Robert E. Ward and Frank J. Shulman with the assistance of Masashi Nishihara and Mary Tobin Espey

This collection marks the culmination of a six year, binational project drawing not only on materials from the United States and Japan, but also Britain, Australia, and the Soviet Union. It contains over 3,000 annotated entries, including books, articles, doctoral dissertations, government publications, and archival materials.

Among the subjects covered in considerable detail are:

- Allied plans for the postwar treatment of Japan

- Steps that led to the signing of the peace treaty in 1951 and the U.S.-Japan Security Treaty

- Revision of the Japanese constitution

- Changes in the Japanese legal and judiciary systems

- Land reforms

- Educational reform

- Zaibatsu deconcentration program

- War Crimes Trials

In addition it provides a broad coverage of the U.S. involvement in the occupation, and attempts to assess the contributions of the occupation period to recent history. This bibliography is truly an important accomplishment in the field of Asian Studies, and an excellent starting point, whatever your interest in this period and its historical and political impact.

$(\# 8389-01271) \quad \$ 50.00$

AMERICAN LIBRARY ASSOCIATION
The Basic Background...

\section{JAPAN AND KOREA} Compiled and edited by Frank J. Shulman

An annotated bibliography of over 2,000 doctoral dissertations from 26 countries, written in 14 Western languages. All entries bear on Japan or Korea in whole or part, and are assembled in classified order. Indexed by author, degree-granting institution, and by personal name for those largely biographical in nature.

(\#8389-0085-2) 360 pages paper $\$ 6.95$

\section{UNIVERSITY AND RESEARCH LIBRARIES IN JAPAN AND THE UNITED STATES}

Thomas R. Buckman, Yukihisa Suzuki, and Warren Tsuneishi, eds.

Proceedings of the First Japan-U.S. Conference on Libraries and Information Science in Higher Education, sponsored jointly by the American and Japanese Library Associations. (\#8389-3111-1)

308 pages $\$ 13.50$

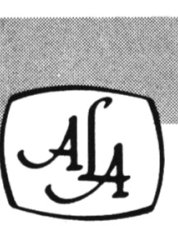

50 East Huron Street, Chicago, Illinois 60611 


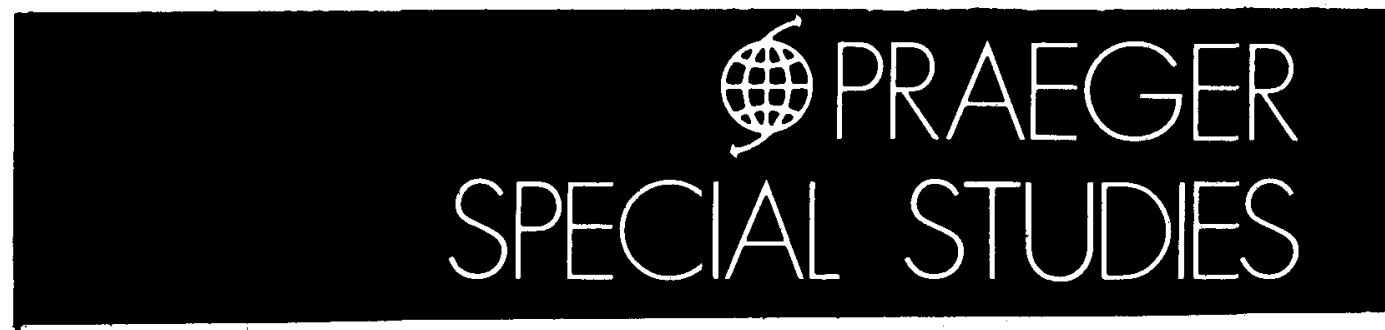

\section{THE ECONOMICS OF} PEACETIME DEFENSE

\section{Murray L. Weidenbaum}

An analysis of the military-industrial complex which concludes that the military budget no Ionger dominates the national economy, as a result of a shift from "warfare to welfare" priorities.

Mar., 1974206 pp. TC $0807 \$ 15.00$

\section{DOCTORS IN POLITICS}

The Political Life of the Japan

Medical Association

William E. Stes/icke

"This thoughtful case study... enhances our understanding of both the Japanese and our society .... I hope that [it] will be widely read ..."

-T. Scott Miyakawa, The Annals of the American Academy.

$1973 \quad 320$ pp. TC $0683 \$ 17.50$

\section{PHILADELPHIA}

Neighborhood, Authority and the Urban Crisis

\section{Conrad Weiler}

Analyzes the city's fiscal and political reforms, ethnic and racial conflicts, and policy issues of housing and urban renewal, transportation, business expansion, school and welfare politics.

Mar., 1974210 pp. TC $0825 \$ 12.50$

\section{ENFORCING AIR}

\section{POLLUTION CONTROLS}

Case Study of New York City

\section{Esther Roditti Schachter}

Finds that local laws directed at controlling air pollution sources have failed because the owner/ operators have nothing to gain by meeting higher operating standards. Published in cooperation with the Center for Policy Research.

1973124 pp. TC $0778 \$ 13.50$

\section{THE INTERNATIONAL POLITICS OF MARINE POLLUTION CONTROL \\ Robert A. Shinn}

Traces development and status of marine pollution in international law, identifies primary interest groups and forums, and analyzes proposals now before the international community. Mar., 1974220 pp. TC $0823 \$ 16.50$
PRIVATE ASSUMPTION OF PUBLIC RESPONSIBILITIES

The Role of American Business in Urban Manpower Programs Peter Kobrak

Evaluates the Job Opportunities in the Business Sector Program (JOBS), conducted by the voluntary National Alliance of Businessmen (NAB), partly under government sponsorship. Encourages assessment in political and social terms of program feedback, accommodating differing parties' goals.

1973276 pp. TC $0703 \$ 17.50$

\section{TELEVISION PROGRAMMING FOR NEWS AND PUBLIC AFFAIRS}

A Quantitative Analysis of Networks and Stations

\section{Frank Wolf}

Examines the factors that shape news and public affairs programming. Studies the economics, ownership structure, and regulation of the broadcast industry, as well as the influence of future programming by cable TV.

1972218 pp. TC $0630 \$ 15.00$

\section{THE USES OF THE MEDIA BY THE CHICANO MOVEMENT A Study in Minority Access \\ Francisco J. Lewels, Jr.}

Documents the sociopolitical aspects of the Chicano civil rights movement. Explains why the media are so important to the civil rights movement and what will be the consequences to the system of mass communication.

Mar., 1974204 pp. TC $0821 \$ 15.00$

\section{POLITICS AND DEVELOPMENT IN RURAL MEXICO}

A Study of Socio-Economic Modernization Manuel L. Carlos

Examines the impact of modernization on community politics and political development in federally established target areas in this Fuerte Valley case study.

Mar., 1974144 pp. TC $0819 \quad \$ 12.50$

Please include TC number when ordering.

Order directly from Qroseg 1114th Ave., New York, N.Y. 10003 


\section{NEW PAPERBACKS IN}

\section{POLITICAL SCIENCE FROM PRAEGER}

\section{THE PRESIDENCY REAPPRAISED}

Edited by Rexford G. Tugwell and Thomas E. Cronin, Center for the Study of Democratic Institutions

Today no course in American Government can avoid paying close and serious attention to the Presidency. The many questions now being raised about the office and the men who occupy it are important not only to students of politics, but to all citizens interested in the current and future state of our system of government. In this timely new collection, several leading presidential scholars address themselves to the central issues now surrounding the Presidency and set forth proposals for reforming and revitalizing the office.
1974
$308 \mathrm{pp}$.
$\$ 3.95$ paper

\section{HOW AMERICAN FOREIGN POLICY IS MADE}

John Spanier and Eric Uslaner,

\section{University of Florida}

This concise book, which is intended primarily for students taking a first course in American Government, is a primer on the formulation of American foreign policy. The authors focus on such important topics as the differences between foreign policy decision-making and domestic policy formation, the roles played by the President and Congress, and the general performance of the United States in foreign policy. Special attention is given to proposed reforms that would give Congress responsibilities in foreign policy-making equal to those of the President.
May, 1974
ca. 192 pp.
$\$ 2.95$ paper

\section{ONE LAST CHANCE}

The Democratic Party, 1974-76

John G. Stewart

Can the Democrats win the Presidency in 1976 ? The author draws lessons from the Democratic Party's continuing victories in gubernatorial and state-legislative contests to outline an effective strategy for internal reform for the critical years 1974 and 1975 . Basing his study on specially commissioned data from the Gallup Organization, he carefully analyzes the Presidential race of 1972 and shows that, to ensure a Democratic Presidential victory in 1976, the party must forge a new coalition with a new ideology-one based on making government work.

May 1974

$224 \mathrm{pp}$

$\$ 3.95$ paper

\section{EXPANSION AND COEXISTENCE \\ Soviet Foreign Policy, 1917-73 \\ Second Edition \\ Adam B. Ulam, Harvard University}

This comprehensive survey of Soviet Russia's international relations shows how the original premises of Soviet diplomacy have been adapted, changed, or preserved during the past fifty years. Completely revised and updated, its authoritative new chapters discuss the personalities of the postKhruschev bureaucratic leadership; the impact of the Viet Nam War (and the decline in American prestige) on Soviet policy; shifts in Soviet policy resulting from the resumption of American-Chinese relations; and the Soviet reaction to the 1973 Middle East crisis.

April, $1974 \quad 808$ pp.

$\$ 6.95$ paper

\section{IDEOLOGY, POLITICS, AND GOVERNMENT IN THE SOVIET UNION UNION}

\section{An Introduction}

\section{Third Edition}

\section{John A. Armstrong, University of Wisconsin}

This thoroughly revised edition begins with an historical overview of Russian politics and a thorough exposition of the formal structure of Soviet political and legal institutions. Professor Armstrong then discusses planning and the economy, the nationalities problem, the affect of domestic necessities upon Soviet foreign policy, and present and future relations between the Soviet Union and China, the West, and the Third World. He concludes with an entirely new final chapter on the interpretation of foreign policy in the Soviet Union.
1974
$256 \mathrm{pp}$.
$\$ 3.50$ paper

\section{praeger}

\section{college department}

\author{
III fourth avenue • new york 10003
}


Excellent for classroom use

AEI's

Distinguished Lectures

on the

\section{United States Bicentennial}

by leading

Americans of letters

Now available in pamphlets.

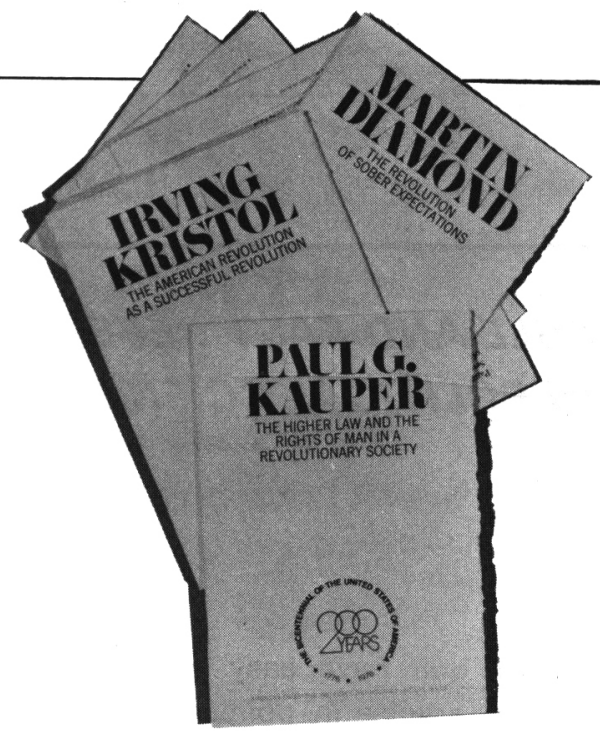

Also televised on the

Public Broadcasting Service

\section{Irving Kristol}

The American Revolution as a

Successful Revolution

Martin Diamond

The Revolution of Sober Expectations

Paul G. Kauper

The Higher Law and the Rights of

Man in a Revolutionary Society

Robert A. Nisbet

The Social Impact of the Revolution

Gordon S. Wood

Revolution and the Political Integration of the Enslaved and Disenfranchised

Caroline Robbins

The Pursuit of Happiness

Peter L. Berger

Religion in a Revolutionary Society

G. Warren Nutter

Freedom in a Revolutionary Economy

\section{Vermont Royster}

The American Press and the

Revolutionary Tradition

\section{AEI Bicentennial Lectures}

$\square$ Please send me the following lectures at $\$ 1.00$ each.

\section{Edward C. Banfield}

Cities as Revolutionary Communities

\section{Leo Marx}

The American Revolution and the

American Landscape

Ronald S. Berman

Intellect and Education

in a Revolutionary Society

Kenneth B. Clark

The American Revolution:

Democratic Politics and Popular Education

Forrest Carlisle Pogue

The Revolutionary Transformation

of the Art of War

\section{Charles Burton Marshall}

American Foreign Policy as a

Dimension of the American Revolution

Dean Rusk

The American Revolution and the Future

Please reserve one copy of bound volume of all 16 lectures. (tentative price $\$ 12.00$ )

Name

Address 


\section{FULL AND FAST REFERENCE IN POLITICAL SCIENCE?}

\section{IPSA TRIES HARD!}

Do you have easy access to the hundreds of journals which publish articles in political science, public administration and international relations all over the world? At a time when many libraries must take a close look at their budgets, can you and your students dispense with the ever fuller and faster services provided by INTERNATIONAL POLITICAL SCIENCE ABSTRACTS?

A non-commercial journal published by the International Political Science Association itself, the Abstracts provides summaries of articles in both specialized and non-specialized journals, including major yearbooks. Articles in English are abstracted in English; articles in other languages (approximately $30 \%$ ) are abstracted in French. From four issues and 2998 abstracts in 1972 (twice more than in 1968) the progress has been to six issues and 4555 abstracts in 1973. Each issue carries a detailed subject index and a list of the periodicals examined; the final issue of each annual volume contains a cumulative subject index and an author index. Back volumes are available.

Your own Library should have a full set of the Abstracts. The institutional subscription for 1974 costs French Francs 225 (approximately $\$ 47, £$ st. 20 ). Individuals may suscribe at a reduced rate of F.F. 100 (approximately $\$ 21, £ 9$ ).

INTERNATIONAL POLITICAL SCIENCE ABSTRACTS

27, RUE SAINT-GUILLAUME, 75007 PARIS, FRANCE 


\section{FROM AEI . . \\ WATERGATE ANDTHE LAW \\ Political Campaigns and Presidential Power}

Ralph K. Winter, Jr.

At the request of the Senate Watergate Committee, this report examines the major issues of the Watergate hearings. The AEI study and others commissioned by the Committee will be used in determining the need for new legislation.

Winter, professor of law at Yale Law School, discusses campaign financing, so-called "Dirty Tricks," executive privilege and power, national security and the advisability of an independent Department of Justice.

A panel of distinguished scholars headed by Professor Alexander M. Bickel of Yale Law School served as consultants. 85 pages

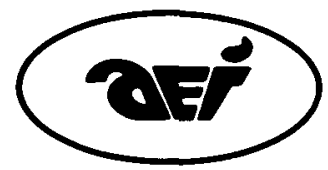

paperback $\$ \mathbf{3 . 0 0}$

\section{American Enterprise Institute for Public Policy Research}

Please send me $\Pi$ copies of Watergate and the Law @ \$3.00 for paperback

Quantity discount information available

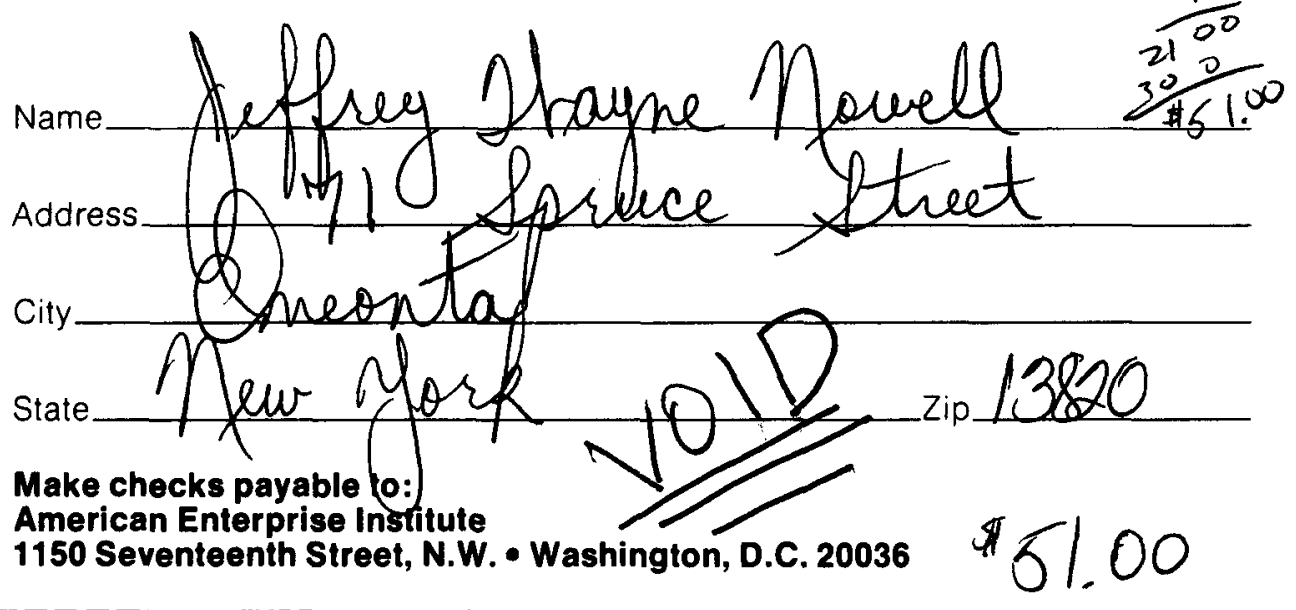


Benefit-Cost and

Policy

Analysis 1973:

An Aldine Annual

on Forecasting,

Decision-Making and Evaluation edited by Robert H. Haveman, Arnold C. Harberger, Laurence E. Lynn, Jr., William A. Niskanen, Ralph Turvey, Richard Zeckhauser, and Daniel Wisecarver

This Annual provides a unique service to professionals and graduate students struggling to keep abreast of current developments in the field. The distinguished Board of Editors reviewed hundreds of papers written during 1973 and selected 22 from among the most important for publication in one compact volume. The selections reflect a shift toward broader evaluations of the efficiency and equity impacts of major policy alternatives-from environmental and natural resources policies to issues of health insurance, income maintenance and public regulation.

512 pp. June $1974 \$ 20.00$ (institutional rate)

$\$ 14.00$ (individual rate) *

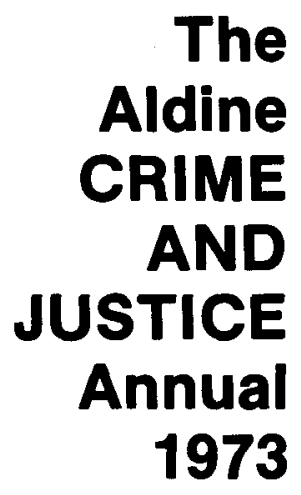

SCALING:

A Sourcebook

for

Behavioral

Scientists

edited by

Gary M. Maranell edited by Sheldon L. Messinger, Seymour L. Halleck, Paul Lerman, Norval Morris, Patrick V. Murphy and Marvin E. Wolfgang

This new Annual provides for the first time in one compact volume a wide range of practical and theoretical material on all aspects of crime and justice. The distinguished Board of Editors reviewed hundreds of papers written during 1973 and assembled 31 from among the most important-a fascinating variety of materials that will serve to bring to your attention many and perhaps most of the important developments in the field. The Aldine CRIME AND JUSTICE Annual 1973 includes an introductory essay pointing up current developments as revealed by the collection.

512 pp. June $1974 \$ 20.00$ (institutional rate) $\$ 14.00$ (individual rate) *

This sourcebook provides an introduction and overview of the measurement techniques appropriate throughout the social sciences. The articles include both classics in the field and the best of modern work. They require no great mathematical sophistication, and go well beyond the conventional study of attitudes to the more general uses of scaling. They enable the reader to examine the development of measures of scalability and the problems and weaknesses they present, to become familiar with the development of tests of significance for reproducibility and scalability and the need for them, to examine the lively history of the subject, and to experience the excitement that can be secured from sharing with a creative author the first report of his insight.

416 pp. April $1974 \$ 15.00$ cloth * 


\section{for Political Scientists}

Response Effects in Surveys:

A Review and Synthesis

Seymour Sudman and Norman M. Bradburn
This book is the first major effort to pull together into a single source the voluminous literature on the subject of response effects, and to develop a model of the major kinds of response error and a general theory of response effect. Users and practitioners of survey methods in all fields will find the book useful as a summary statement of important principles of sound research methods and a guide to the improvement of survey work.

264 pp. June $1974 \$ 11.50$ cloth
The Economic Theory of Representative Government

Albert Breton
This pathbreaking book presents a theory capable of "explaining" the patterns of public expenditure and taxation that occur under representative government. Dr. Breton suggests that government be understood as one of the major economic institutions of society, one that behaves like more familiar economic institutions-the household and the firm-though the market it confronts is a market for policies rather than goods and services. Thus the reader is better able to understand the observed behavior of our enormously important political institutions.

232 pp. April $1974 \$ 8.50$ cloth
Great Issues of International Politics (Second Edition) edited by Morton A. Kaplan
The first edition of this book was widely recognized as an indispensable sourcebook that brought excitement and relevance to the study of international politics and foreign policy by presenting a vigorous clash of opinions on the most pressing issues of our times. The second edition has been reorganized, greatly expanded and completely updated-providing a rich mine of vital insights into the evaluation of the great issues of international politics, and an irresistible stimulus to critical debate.

$612 \mathrm{pp}$. January $1974 \$ 17.50$ cloth *
Measurement in the

Social Sciences: Theories and Strategles

edited by H. M. Blalock, Jr.
This book deals with selected problems of measurement and is written for graduate students and professionals, particularly in the technically less developed areas of social science. It represents a series of studies of topics deemed to be crucial for the advancement of social science research, but which have not received sufficient attention. The basic purpose is to stimulate further methodological research and to study ways in which knowledge accumulated in some fields may be generalized so that it may be applied to others.

512 pp. July $1974 \$ 16.00$ cloth *

* a text edition is available for classroom use 


\section{This IS NOT another textbook . . .}

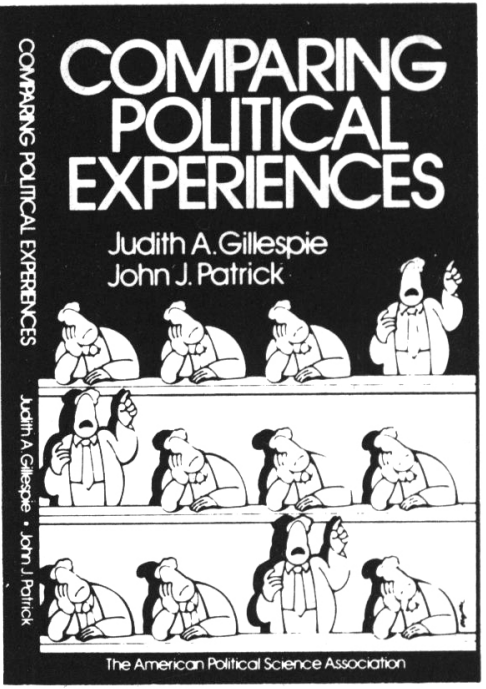

\section{It IS a complete description of an alternative to high school government instruction.}

A new approach to pre-collegiate political science education is detailed in this book. Rationale, development, and dissemination phases of the course are outlined, with special attention to instructional objectives and methodology.

Political systems are compared across school, local, national, and international levels. Inquiry and action are integrated by testing hypotheses about everyday political life, and practicing participation skills in the high school. The high school as a political laboratory is a unique focus of the course.

Prototype testing of the course is currently being conducted in high schools across the nation by the Social Studies Development Center at Indiana University, Bloomington, Indiana. The course is a project of the APSA Pre-Collegiate Education Committee.

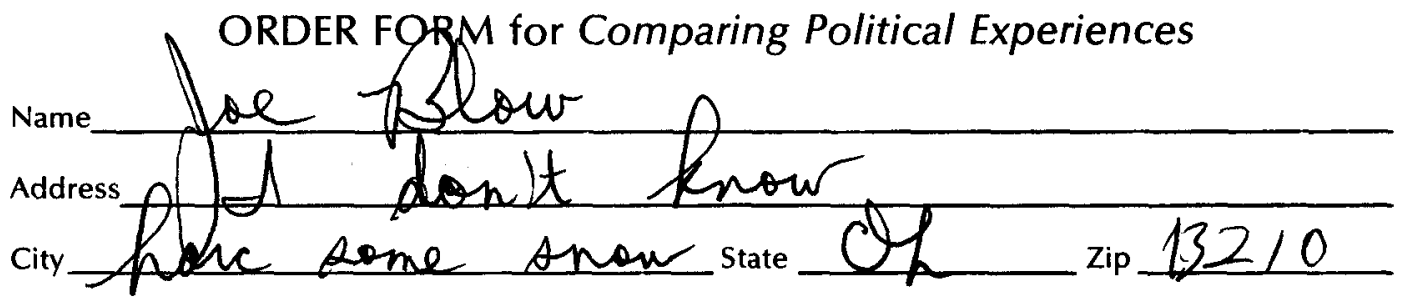

Send form prepaid in the amount of $\$ 2.75$ to:

American Political Science Association 1527 New Hampshire Avenue, N.W.

Washington, D.C. 20036 


\section{The best deal on life insurance,}

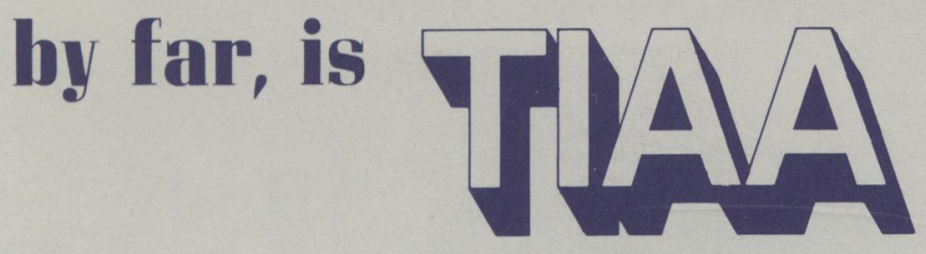

Studies reported recently in independent consumer publications confirm the cost of TIAA life insurance is substantially less than that for policies sold through life insurance companies that serve the general public. These reports are must reading for insurance shoppers; if you haven't seen them we'll be glad to direct you to them.

These days, when it's more important than ever to squeeze the most from every dollar, it makes more sense than ever for college employees and other eligible persons to look to TIAA for the new life insurance they need. By the way, TIAA policies include the unique "Cost of Living" provision to help prevent inflation from nibbling away the purchasing power of the death protection.

While TIAA offers plans to meet different situations, and a free advisory service to help select the right plan, most educators with TIAA policies prefer Term insurance because with Term they can easily afford to carry the high level of family protection they need. For example: $\$ \mathbf{1 0 0 , 0 0 0}$ of decreasing Term insurance costs only $\$ 185$ at age 30 .

\begin{tabular}{|c|c|c|c|c|}
\hline Here are illustrative cost figures for differe & & $\$ 100,00020$-Year & Home Protection & Policy \\
\hline $\begin{array}{l}\text { Age at Issue } \\
\text { Annual Premium (Payable only } 16 \text { years) } \\
\text { Cash Dividend End of First Year }\end{array}$ & $\begin{array}{c}25 \\
\$ 268.00 \\
122.00\end{array}$ & $\begin{array}{r}30 \\
\$ 318.00 \\
133.00\end{array}$ & $\begin{array}{c}35 \\
\$ 413.00 \\
154.00\end{array}$ & $\begin{array}{r}40 \\
\$ 580.00 \\
191.00\end{array}$ \\
\hline First Year Net Premium & $\$ 146.00$ & $\$ 185.00$ & $\$ 259.00$ & $\$ 389.00$ \\
\hline
\end{tabular}

This Home Protection policy is level premium Term insurance that gives its highest amount of protection initially, reducing by schedule over a 20 year period to recognize decreasing insurance needs. Home Protection policies are available for several other insurance periods in amounts of $\$ 5,000$ or more and are issued at ages under 56 .

\section{E L I G I B I L I T Y}

to apply for TIAA policies is limited to employees of colleges, universities, and certain other nonprofit educational institutions that qualify for TIAA. If you are eligible, complete and send the coupon so we can mail the Life Insurance Guide and a personal illustration of TIAA policies issued at your age. TIAA is nonprofit and employs no agents.

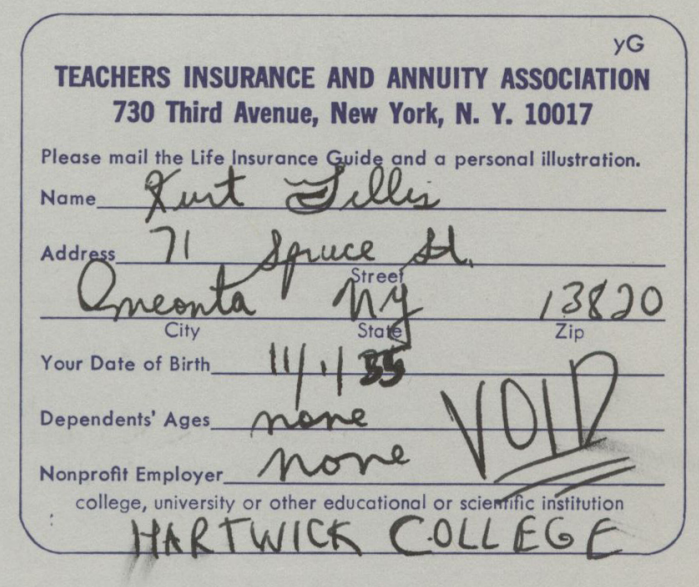




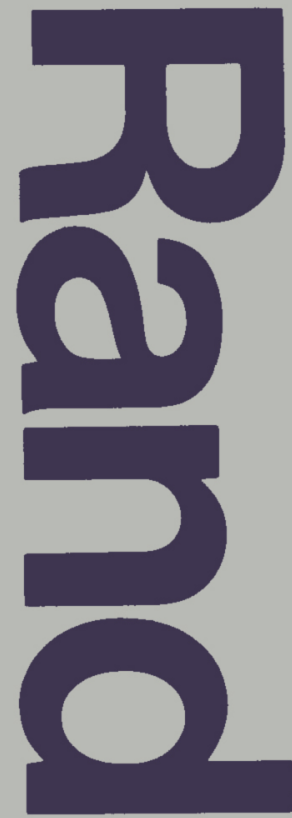

NEW MARKHAM TITLES

\section{INTRODUCTION TO INTERNATIONAL POLITICS:}

A Theoretical Overview / Second Edition

William D. Coplin, Syracuse University

Widely adopted in its first edition, the new second edition of this popular core text maintains the highly acclaimed features of the original-its concise, clear writing; its keen analysis of concepts; and its systematic development of a comprehensive framework for international politicsadding a new last chapter on world order and its value implications. c. 400 pages, $\$ 8.95$ Cloth / Instructor's Manual

\section{INTRODUCTORY CASE STUDIES FOR INTERNATIONAL RELATIONS: Vietnam, The Middle East, and the Environmental Crisis}

John R. Handelman, Washington and Lee University; Howard B. Shapiro, Syracuse University; John A. Vasquez, Syracuse University

In this short text, three conceptual frameworks are presented and applied to specific cases. The authors offer a concise set of tools for interpreting global issues and show how different frameworks lead to alternative explanations of events. c. 160 pages, $\$ 2.95$ Paper

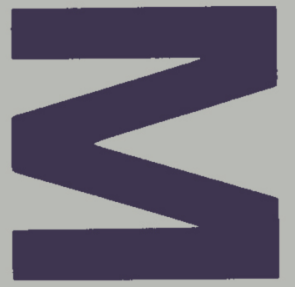

\section{AMERICAN IDEOLOGIES: The Competing Political Beliefs of the 1970 s Second Edition}

Kenneth M. Dolbeare, University of Washington; Patricia Dolbeare; with Jane Hadley, University of Washington

The new expanded edition of this highly successful text provides further insight into the dynamics of American politics, analyzing both mainstream ideologies and the beliefs of the "change-seekers"-Blacks, Chicanos, Indians, Women, the New Left, etc. The final chapter discusses the implications that these political conflicts hold for the future. 280 pages, $\$ 3.50$ Paper, $\$ 7.95$ Cloth

\section{WIDELY ADOPTED}

\section{DEMOCRACY IN THE UNITED STATES: Promise and Performance Second Edition}

\section{Robert A. Dahl, Yale University}

Professor Dahl clearly describes, explains, and evaluates the American political system in terms of its promise and performance. His approach is eclectic and his appraisals critical. This text will not only add to students' knowledge of political institutions, but also provide them with an understanding of American political development, a sense of the gap between the democratic ideal and the American reality, and a perspective for further examining political systems. 453 pages, $\$ 7.50$ Paper / Instructor's Manual
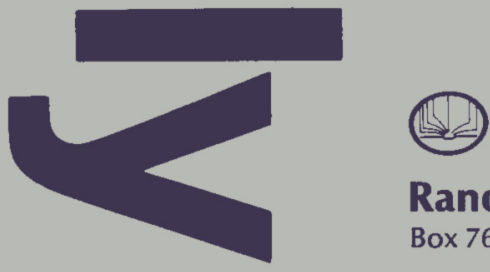

\section{Rand MSNally College Publishing Company}

Box 7600 / Chicago, Illinois 60680 